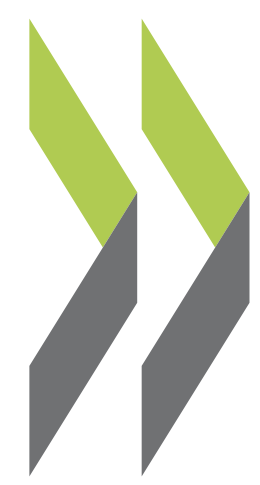

OECD Economics Department Working Papers No. 984

Portugal - Assessing the Risks Around the Speed of Fiscal Consolidation in an Uncertain Environment

\section{Stéphane Sorbe}

https://dx.doi.org/10.1787/5k92smzp0b6h-en 
Organisation de Coopération et de Développement Économiques

Organisation for Economic Co-operation and Development

19-Sep-2012

ECONOMICS DEPARTMENT

English - Or. English

PORTUGAL: ASSESSING THE RISKS AROUND THE SPEED OF FISCAL CONSOLIDATION IN AN UNCERTAIN ENVIRONMENT

ECONOMICS DEPARTMENT WORKING PAPERS No. 984

By Stéphane Sorbe

All OECD Economics Department Working Papers are available through OECD's Internet website at http://www.oecd.org/eco/workingpapers

JT03326447

Complete document available on OLIS in its original format

This document and any map included herein are without prejudice to the status of or sovereignty over any territory, to the delimitation of international frontiers and boundaries and to the name of any territory, city or area. 


\section{ABSTRACT/RESUMÉ \\ Portugal: assessing the risks around the speed of fiscal consolidation in an uncertain environment}

This paper illustrates possible trade-offs between two different fiscal consolidation strategies in Portugal: sticking to the nominal fiscal targets in the EU-IMF programme or allowing automatic stabilisers to work, while sticking to the structural primary deficit targets implied by the programme. The analysis is based on stochastic simulations in which random shocks affect the main economic variables in the framework of a small macroeconomic model. The model captures the mutual interdependences between the fiscal position, financial conditions and activity and notably the impact of public debt developments on investors' confidence and interest rates. Results suggest that under the large fiscal consolidation programme that is currently implemented, both fiscal policy strategies considered would in most cases result in sustainable debt dynamics. Both strategies also entail risks, but of a different nature: the risk of a deeper recession if sticking to nominal targets and the risk of higher debt if letting automatic stabilisers play. Sensitivity analyses show that these risks could be reduced by stimulating potential growth through structural reform and by choosing "growth friendly" fiscal consolidation instruments that have lower multipliers. By reducing recessionary risks, a small fiscal multiplier also increases the relative benefits of sticking to nominal deficit targets, while the benefits of automatic stabilisers are larger if the multiplier is high.

This Working Paper relates to the 2012 OECD Economic Survey of Portugal (www.oecd.org/eco/surveys/portugal).

JEL classification: C53, E62, H63

Keywords: Portugal; public debt sustainability; risk analysis; fan charts; automatic stabilisers; fiscal multiplier

$* * * * * * * * * * * *$

\section{Portugal : évaluer les risques autour du rythme d'assainissement budgétaire dans un environnement incertain}

Ce document illustre les compromis possibles entre deux stratégies de consolidation budgétaire au Portugal : respecter les cibles budgétaires nominales du programme de l'Union Européenne et du FMI ou laisser jouer les stabilisateurs automatiques tout en respectant les objectifs de déficit structurel primaire impliqués par le programme. L'analyse se fonde sur des simulations stochastiques dans lesquelles des chocs aléatoires affectent les principales variables économiques dans le cadre d'un petit modèle macroéconomique. Le modèle tient compte des interdépendances mutuelles entre la situation budgétaire, les conditions financières et l'activité, et notamment l'impact de l'évolution de la dette publique sur la confiance des investisseurs et les taux d'intérêt. Les résultats suggèrent que, dans le cadre du programme d'assainissement budgétaire important qui est actuellement mis en œuvre, les deux stratégies budgétaires considérées se traduiraient dans la plupart des cas par une dynamique d'endettement soutenable. Ces deux stratégies comportent également des risques, mais de nature différente : le risque d'une récession plus marquée si les cibles nominales sont respectées et le risque d'une dette plus élevée en laissant jouer les stabilisateurs automatiques. Les analyses de sensibilité des résultats montrent que ces risques pourraient être réduits en stimulant le potentiel de croissance de l'économie par des réformes structurelles et en choisissant des instruments de consolidation budgétaires favorables à la croissance, c'est-à-dire avec de plus faibles multiplicateurs. En réduisant les risques de récession, un multiplicateur budgétaire faible augmente aussi les avantages relatifs de respecter les cibles budgétaires nominales, tandis que les avantages des stabilisateurs automatiques sont d'autant plus grands que le multiplicateur est élevé.

Ce Document de travail se rapporte à l'Étude économique de l'OCDE du Portugal, 2012 (www.oecd.org/eco/etudes/portugal).

Classification JEL: C53, E62, H63

Mots-clés: Portugal ; viabilité de la dette publique ; analyse de risques ; graphiques en éventail ; stabilisateurs automatiques ; multiplicateur budgétaire

(c) OECD (2012)

You can copy, download or print OECD content for your own use, and you can include excerpts from OECD publications, databases and multimedia products in your own documents, presentations, blogs, websites and teaching materials, provided that suitable acknowledgment of OECD as source and copyright owner is given. All requests for commercial use and translation rights should be submitted to rights@oecd.org. 


\section{TABLE OF CONTENTS}

Portugal: Assessing the risks around the speed of fiscal consolidation in an uncertain environment ............ 5

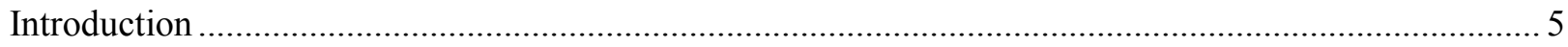

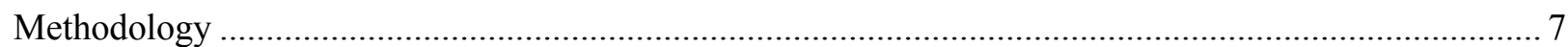

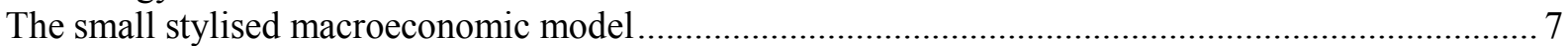

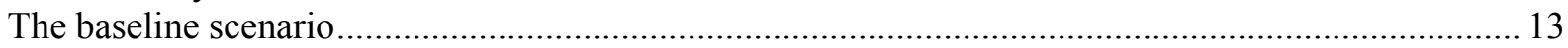

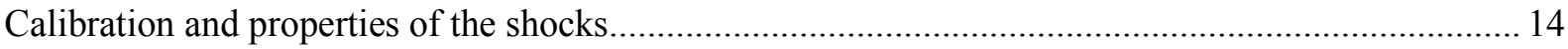

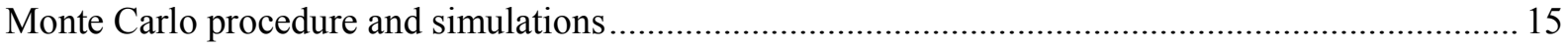

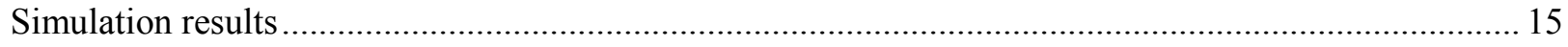

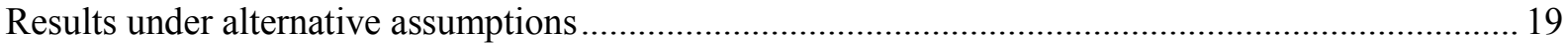

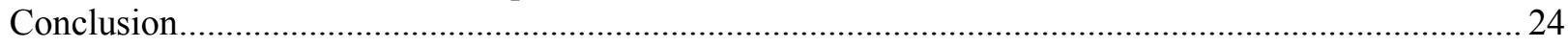

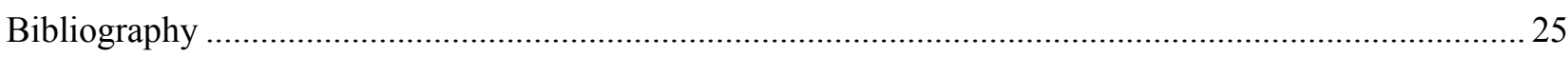

\section{Tables}

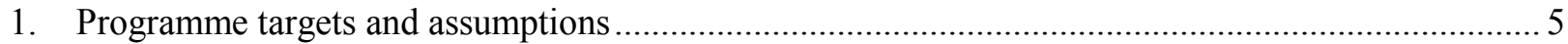

2. Portugal's government main sources of financing in the baseline scenario .................................... 12

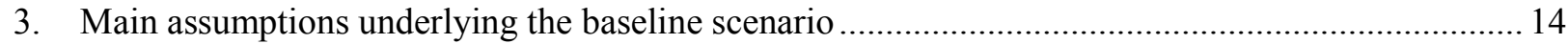

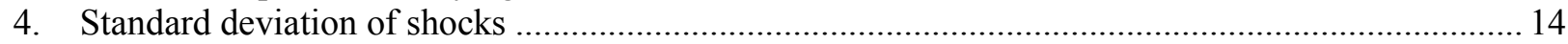

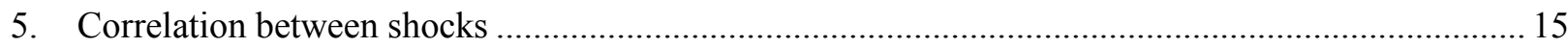

\section{Figures}

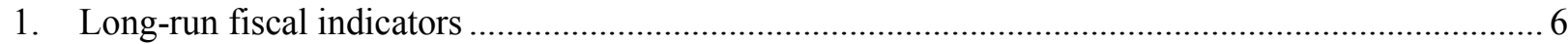

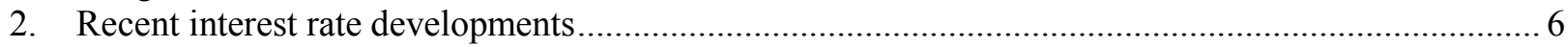

3. Calibration of the interest rate spreads' distribution as a function of public debt dynamics

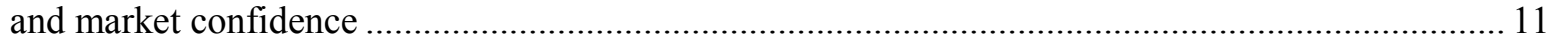

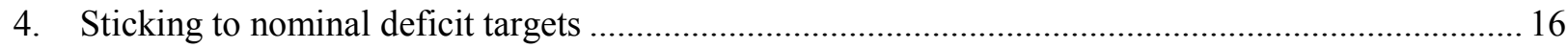

5. Letting automatic stabilisers play (respecting primary structural deficit targets) ............................. 18

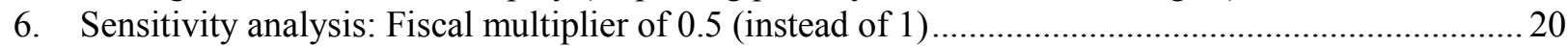

7. Sensitivity analysis: Fiscal multiplier of 1.5 (instead of 1) ......................................................... 21

8. Sensitivity analysis: Average potential growth over $2012-16$ of $-0.5 \%$ (instead of $+0.3 \%) \ldots \ldots \ldots \ldots .22$

9. Sensitivity analysis: Average potential growth over $2012-16$ of $+1 \%$ (instead of $+0.3 \%$ ).............. 23

10. Sensitivity analysis: Programme financing extended after 2013 if nominal deficit targets are met... 24 
ECO/WKP(2012)61 


\title{
PORTUGAL: ASSESSING THE RISKS AROUND THE SPEED OF FISCAL CONSOLIDATION IN AN UNCERTAIN ENVIRONMENT
}

\author{
by Stéphane Sorbe ${ }^{1}$
}

\section{Introduction}

In May 2011, Portugal entered an EU-IMF financial assistance programme, as rapidly rising public debt and deteriorating growth prospects led financial markets to lose confidence in the country's sovereign debt, pushing interest rates to unsustainably high levels (Figures 1 and 2). The programme is providing loans amounting to EUR 78 billion (45\% of GDP), covering most of the government's financing needs until September 2013, while a large fiscal consolidation programme is being implemented. The aim is to reduce the public deficit from 10\% of GDP in 2010 to 3\% of GDP in 2013 despite the headwinds of a severe recession in 2011-12 that is projected to end in 2013 (Table 1).

Table 1. Programme targets and assumptions

Per cent of GDP ${ }^{1}$

\begin{tabular}{lrr|rrrrr}
\hline & \multirow{2}{*}{2010} & \multirow{5}{|c}{ Targets and assumptions } \\
\cline { 4 - 8 } & & 2011 & 2012 & 2013 & 2014 & 2015 & 2016 \\
\hline Public balance & -9.8 & $-4.2^{1}$ & -4.5 & -3.0 & -1.8 & -1.0 & -0.5 \\
Expenditure & 51.3 & 48.9 & 47.5 & 45.9 & 44.6 & 43.8 & 43.0 \\
Revenue & 41.4 & 44.7 & 42.9 & 42.9 & 42.8 & 42.7 & 42.5 \\
Public debt (Maastricht definition) & 93.3 & 107.8 & 113.1 & 115.7 & 113.4 & 109.5 & 103.9 \\
Real GDP growth (\%) & 1.4 & -1.6 & -3.0 & 0.6 & 2.0 & 2.4 & 2.8 \\
\hline
\end{tabular}

1. Revenue and balance include a number of one-offs, of which the most notable is a positive one in 2011 of $3 \frac{1}{2}$ per cent of GDP, corresponding to the transfer to the government of the assets of banks' pension funds, in exchange for overtaking future pension liabilities.

2. Source: OECD (2012), OECD Economic Outlook: Statistics and Projections (database), May for historical series of 2010-11 and Ministry of Finance (2012), Documento de Estratégia Orçamental 2012-2016 for targets and assumptions of 2012-16.

1. OECD, Economics Department. The author is grateful to Pierre Beynet, Andrew Dean, Robert Ford, David Haugh, Lukasz Rawdanowicz and Jean-Luc Schneider for valuable comments and suggestions. Special thanks go to Desney Erb for statistical assistance. 


\section{Figure 1. Long-run fiscal indicators}

Per cent of GDP

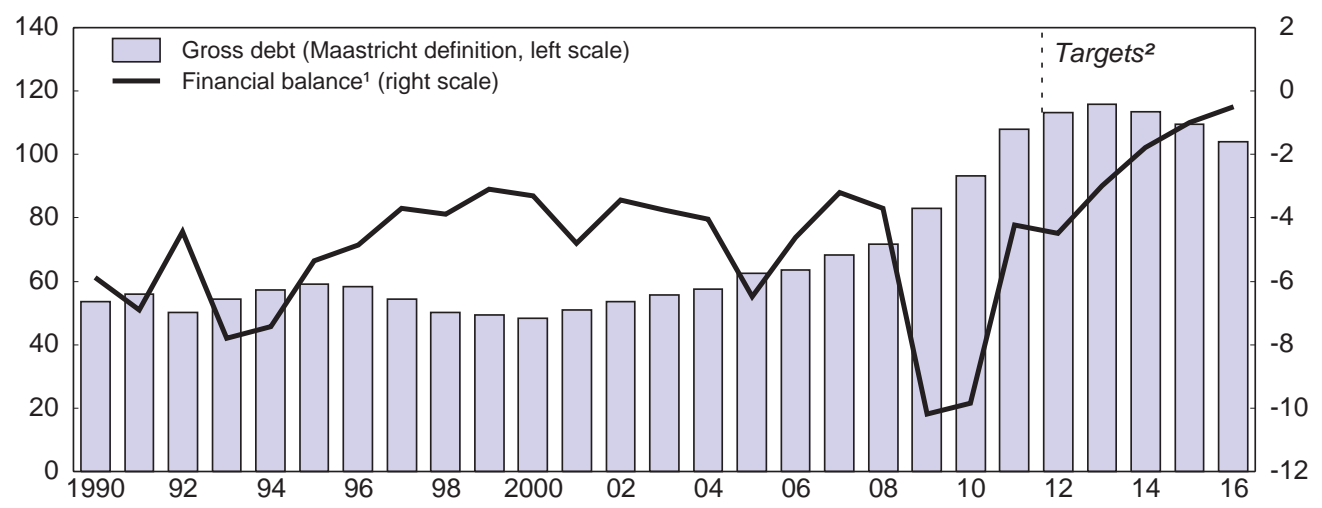

1. This includes a number of one-offs of which the most notable is a positive one in 2011 of $3 \frac{1}{2}$ per cent of GDP corresponding to the transfer to the government of the assets of banks' pension funds, in exchange for overtaking future pension liabilities.

2. Stability programme targets for 2012-16.

Source: OECD (2012), OECD Economic Outlook: Statistics and Projections (database), May and Ministry of Finance (2012), Documento de Estratégia Orçamental 2012-2016.

Figure 2. Recent interest rate developments

Per cent, monthly data

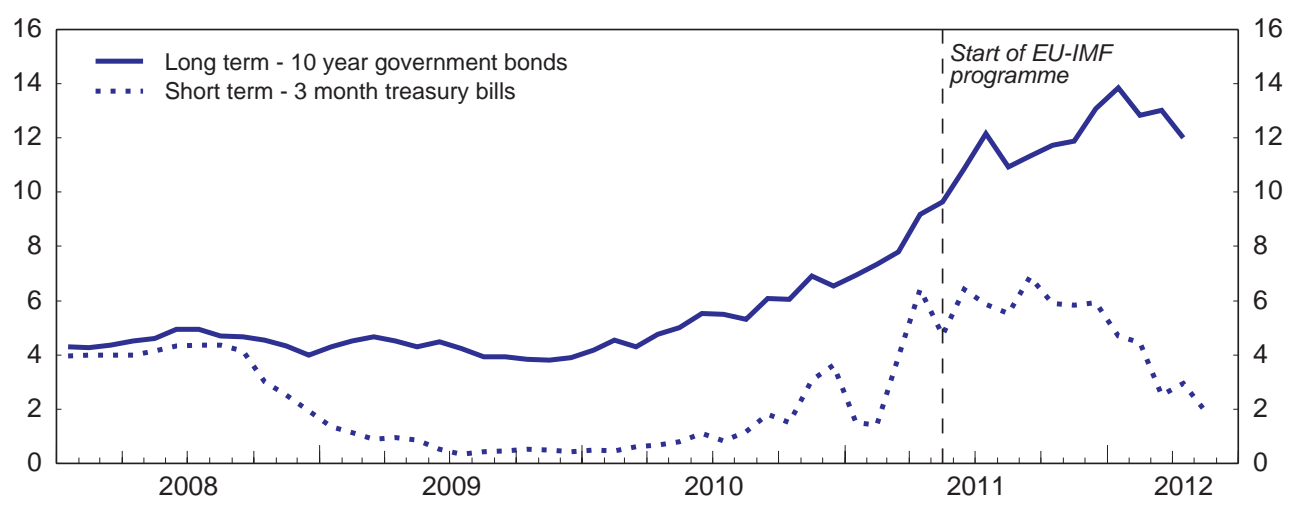

Source: OECD (2012), Main Economic Indicators (database), June and Blomberg.

Under the OECD's central scenario of a gradual economic recovery beginning in 2013 (OECD, 2012), the pace of fiscal consolidation planned by the Portuguese authorities would result in sustainable public debt dynamics. Public debt would peak at 120\% of GDP in 2013 before declining. However, if downside risks to the economic outlook materialise, meeting the programme's nominal deficit targets would require additional consolidation measures. An alternative is to allow the automatic stabilisers to work, which would imply larger fiscal deficits. 
This paper illustrates the economic trade-offs implied by this choice - sticking to nominal deficit targets or letting automatic stabilisers play - in an uncertain environment. To this end, instead of a "static" debt sustainability analysis, as presented for example in European Commission (2012), ECB (2012) or IMF (2012), this paper presents stochastic simulations in which random shocks affect the main economic variables (GDP growth, interest rates, etc), following the approach developed by Celasun et al. (2006) and implemented in a simplified way by di Giovanni and Gardner (2008) and Beynet and Paviot (2012).

These random shocks are calibrated on the basis of past observations and fed into a small-sized stylised macroeconomic model, inspired by Lenain et al. (2010), to derive the probabilities associated with the path of the different variables. The model aims to capture the interdependences between activity, the fiscal position and financial conditions, which are the main relevant transmission channels in the current circumstances. More precisely, the model takes into account: $i$ ) the impact of interest rates and of fiscal consolidation on activity, ii) the feedback of activity and interest rates on the fiscal position and iii) the impact of public debt dynamics on investors' confidence and thus on interest rates on Portuguese bonds. Using a small-scale model brings several benefits over relying on a VAR model, as in Celasun et al. (2006), or on a large macro-model such as NiGEM, as in Barrell et al. (2012). It gives flexibility in the definition of the fiscal policy rule and allows assessing the sensitivity of results to different model assumptions, for example regarding potential growth or the fiscal multiplier.

\section{Methodology}

The small macroeconomic model is used both to assess the historical distribution of shocks and for projections. It comprises economic relationships (e.g. Philips curve, Okun's law), which are partly estimated and partly calibrated, as well as accounting identities. The baseline scenario, to which shocks are applied, consists of the latest OECD projections for 2012-13 (OECD, 2012), which are prolonged for 2014-16 with the scenario underlying the EU-IMF programme (IMF, 2012) ${ }^{2}$ and the most recent official deficit targets (Portuguese Government, 2012) ${ }^{3}$.

Sets of random shocks are drawn jointly for each year of the projection period, based on past observations. Shocks are fed into the model along with a fiscal policy strategy to derive how the path of each variable deviates from its baseline. The drawing of shocks is repeated for a large number of times in a Monte Carlo procedure, yielding confidence intervals for the path of the different variables. Finally, these intervals are represented in fan-charts.

\section{The small stylised macroeconomic model}

The model has neoclassical foundations, in the sense that real GDP is anchored to its potential in the long-term, but incorporates Keynesian effects in the short-term, notably a negative impact of fiscal consolidation on activity. Prices are anchored to the central bank's target in the long run but are also

2. For 2014-16, another possible baseline scenario would have been the OECD's medium term baseline scenario (OECD, 2012). Instead, the scenario underlying the EU-IMF programme has been chosen as it is specifically designed for Portugal for the time-horizon used in this paper (2016) and as it takes into account more precisely specificities such as the planned pace of fiscal consolidation.

3. Another (simpler) option would have been to rely directly on the model to provide the baseline scenario, which would have consisted of the model's output in a no-shock scenario (with some assumptions regarding exogenous variables). However, it would have arguably been a less robust approach as the projections provided by such a small model are likely to be less accurate than the OECD and IMF ones, which are realised in a more detailed and elaborate way. 
influenced by anticipated inflation (proxied by observed inflation) and by the economy's position in the cycle. The path of unemployment is derived from real GDP growth through an estimated Okun's law relationship. Long-term interest rates are the sum of the "risk-free" rate on German bonds and of a spread, which is assumed to depend non-linearly on the public debt dynamics and on a random parameter representing financial market confidence (the exact specification is described below). The estimation period is 1995-2011, reflecting that 1995 was the beginning of a period of moderate inflation after several years of high inflation and can thus be considered a structural break. The source of all data (including potential growth) is OECD Economic Outlook No 91 database. The frequency of all data is annual.

The difference between actual real GDP growth $(g)$ and potential growth ( $\left.g_{-} p o t\right)$ is assumed to depend on the position of the economy in the cycle, financial conditions, fiscal policy and random shocks (equation 1). The model is calibrated so that one fifth of the output gap (GAP) is closed every year (in the absence of other shocks), consistently with assumptions from OECD's medium term baseline scenario (OECD, 2012). The impact of financial conditions in a broad sense on growth is proxied by the change in real long-term interest rates $(\Delta(I R L-p))$, with an estimated coefficient of 0.33 . This coefficient appears consistent with precedent estimations of the impact of financial conditions on activity in the euro area (Guichard et al., 2009) ${ }^{4}$. As trends in public debt have an impact on interest rates in the model (equation 5), this financial conditions channel notably captures that a successful fiscal consolidation would have a positive effect on investors' confidence and thus on credit conditions and activity.

$$
g_{t}=g_{-} p_{p} t_{t}-0.20 G A P_{t-1}-0.33 \Delta\left(I R L_{t-1}-p_{t-1}\right)-0.67 \Delta N L G X U_{t}-0.33 \Delta N L G X U_{t-1}+\varepsilon_{g, t}
$$

The fiscal multiplier, i.e. the direct impact on growth of a $1 \%$ of GDP change in the structural primary balance $(N L G X U)$, is assumed to be one. Two thirds of the impact is assumed to take place in the first year and the other third in the following year, as certain budgetary measures may impact activity with a lag $^{5}$. For the sake of simplicity, no distinction is made between different consolidation instruments.

A multiplier of one is rather high relative to estimates available in the literature. The NiGEM model's average multiplier for Portugal ranges from 0.1 to 0.7 depending on the consolidation instrument (Barrell et al., 2012). Almedia et al. (2011) estimate it between 0.2 and 1.0 on the basis of a dynamic stochastic general equilibrium (DSGE) model and Dias and Lopez (2009) between 0.4 and 1.5 using a multisectoral macroeconometric model. Given the substantial uncertainties about the value of the multiplier, this paper presents results for alternative multipliers. The relatively high multiplier assumed in the baseline reflects the view that the depressed domestic demand and tight credit

4. According to Guichard et al. (2009), a 100 basis point increase in the long-term real interest rate in the euro area reduces GDP by an average $0.19 \%$ after 4 to 6 quarters. This is somewhat lower than the $0.33 \%$ of GDP obtained in equation 1, suggesting that long-term interest rates in equation 1 are a proxy for broader financial conditions. For example, according to Guichard et al. (2009), the cumulated impact of a 100 basis point increase in the short-term real interest rate and similar increases in the long-term real interest rate and corporate bond spreads is $0.32 \%$ of GDP.

5. Indeed, economic agents can be expected to smooth their spending patterns in reaction to revenue shocks, delaying part of the impact of these shocks on activity. In addition, private employment generally reacts with a lag to GDP shocks, potentially affecting households' revenue and ultimately consumption several quarters after the budgetary measures. Simulations run with the NiGEM model suggest that broadly two thirds of the effect of consolidation on activity takes place on the first year, with the other third taking place over the two following years. 
conditions that now characterise Portugal are likely to amplify the impact of fiscal consolidation. Indeed, there is evidence that multipliers tend to be unusually high during times of financial crisis (Corsetti et al., 2012; Boussard et al., 2012) as tight credit conditions leave households and companies less scope to smooth their consumption and investment patterns. In addition, in normal times one might expect a monetary policy offset to reduce the multiplier, thereby lowering its estimated value ; such an offset is assumed not to exist in these simulations.

The residual $\varepsilon_{g, t}$ of equation (1) represents the effect on GDP growth of shocks other than those from fiscal policy, financial conditions and the influence of the position of the economy in the cycle. For example, these shocks can include shocks to Portuguese exports resulting from changes in external demand for Portuguese goods and services. The residual $\varepsilon_{g, t}$ is measured over the estimation period and its properties serve to calibrate the random shocks affecting GDP growth in the projections. More precisely, these shocks are assumed to follow a normal distribution with the same variance as $\varepsilon_{g, t}$ and the same correlation with shocks affecting other variables as $\varepsilon_{g, t}$ has with residuals of other equations.

Inflation $(p)$ is measured by the annual growth rate of the GDP deflator and is determined by a reduced-form Phillips curve (equation 2). It is anchored to the central bank's target in the long run $\left(p^{*}=2 \%\right)$ and also depends on lagged inflation and the output gap $(G A P)$ in the short run. All coefficients of equation (2) are estimated. As for equation (1), the residuals $\varepsilon_{p, t}$ reflect the impact of other shocks, for example external price shocks, and their statistical properties (variance and variable cross-correlation) are used to calibrate the shocks affecting inflation in the projections.

$$
p_{t}=0.54 p^{*}+0.46 p_{t-1}+0.19 G A P_{t-1}+\varepsilon_{p, t}
$$

The evolution of the unemployment rate $(U N R)$ is derived from an estimated Okun's law relationship. It depends on current and lagged growth of real GDP. Residuals $\left(\varepsilon_{U N R, t}\right)$ reflect shocks to unemployment that are not directly related to economic growth and are used to calibrate future unemployment shocks.

$$
\Delta U N R_{t}=1.11-0.27 g_{t}-0.14 g_{t-1}+\varepsilon_{U N R, t}
$$

The interest rate on 10-year government bonds $(I R L)$ is the sum of the "risk-free" rate on German bonds $\left(I R L_{-} G e r\right)$ and a risk-premium (Spread): $I R L_{t}=I R L_{-} G_{e r}+$ Spread $_{t}$. The rate on German bonds is exogenous but subject to shocks, while the spread is endogenous as it depends on the fiscal position. Shocks on German bonds rates are calibrated using the statistical properties of past interest rate changes $\left(\varepsilon_{I R L_{-} G e r, t}\right)$, as measured in equation (4). The constant term in equation (4) only reflects that interest rates on German bonds have declined over the estimation period, by an average $0.25 \%$ per year, but has no impact on projections, which are built around an exogenous (and rising) path of German bond rates.

$$
\Delta I R L_{-} G e r_{t}=-0.25+\varepsilon_{I R L_{-} G e r, t}
$$

The spread of 10-year government bonds over German bonds (Spread) is assumed to depend on financial market confidence and on public debt dynamics in a non-linear way. This non-linearity has notably been exposed by Ardagna et al. (2004) and confirmed by observations during the euro area sovereign debt crisis. The idea is that spreads can rapidly explode when debt is rising if financial markets lose confidence. In contrast, when the public debt ratio is low or on a downward trend, spreads can be 
expected to stay relatively low and to be subject to less volatility. The problem is that the economic and fiscal position that triggers a market loss of confidence is uncertain and also depends on markets' broader risk aversion level, including their confidence in EU level policy decisions to tackle the sovereign debt crisis. For example, the spread on Portuguese bonds has fluctuated widely during the first five months of 2012 , evolving in a range between less than $9 \%$ and more than $14 \%{ }^{6}$.

To reflect these considerations, we assume the logarithm of spreads - using the logarithm provides the sought after non-linearity - to depend on the change in public debt to GDP ratio over the last three years $\left(P \text { Debt }_{t}-P \text { Debt }_{t-3}\right)^{7}$, as a measure of the trend in the debt dynamics, and of a random parameter reflecting market confidence (Market_conf) (equation 5). This parameter is assumed to be exogenous and is drawn randomly for each Monte Carlo simulation and each year, following a normal distribution calibrated as presented in Figure 3. This specification voluntarily leaves aside other potential determinants of spreads, such as the public deficit, the level of public debt (in contrast to its evolution) and potential or $\mathrm{actual}^{8}$ GDP growth. Indeed, their respective influence is difficult to quantify, especially in a non-linear framework. Moreover, focusing only on the evolution of public debt - which is itself directly influenced by the public deficit and GDP growth - offers the benefit of simplicity and transparency, as the current calibration can be directly represented on the single Figure 3. Finally, given the relatively short projection horizon (2016), the level of public debt would add relatively little information, as it will essentially depend on the three-year debt dynamics.

$$
\log \left(\operatorname{Spread}_{t}\right)=0.05\left(\text { PDebt }_{t}-\text { PDebt }_{t-3}\right)+\text { Market_conf }_{-}
$$

The calibration of market confidence allows it to evolve between a "high confidence" and a "low confidence" situation. "High confidence" corresponds to the early 2009 situation, before markets' concerns about sovereign risk in the euro area progressively started to increase. The idea is that the very high market confidence observed between 1997 and 2008, when spreads remained extremely low even when public debt was increasing, is very unlikely to materialise again over the projection period. Indeed, Portuguese public debt is now much higher and the focus on sovereign risks in the euro area has increased considerably. The state of "average" market confidence corresponds broadly to the situation observed since mid-2011, reflecting the idea that this situation represents a balance between upside and downside risks and that confidence can evolve in both directions from its current level. This situation of "average" confidence is also consistent with the baseline scenario. The "low confidence" situation had not arisen in the past, but could be interpreted as representing the materialisation of a downside scenario such as an intensification of the European sovereign debt crisis, as outlined in Box 1.5 of OECD (2011).

6. This volatility may also reflect to some extent a lack of liquidity on the market for Portuguese bonds.

7. The data on PDebt $t$ is not public at the time when Spread $t$ is determined on the market, as debt data are published with a lag, so the model rests on the assumption that market participants use their rational expectations of what PDebt $t$ will be when determining the spread.

8. Potential growth should in theory influence spreads more than actual growth, as it is more relevant to fiscal sustainability. However, possibly because of the unobserved nature of potential growth, actual GDP growth seems to have more influence on spreads (Cottarelli and Jaramillo, 2012). The decline in Irish spreads over the second half of 2012 in the wake of a pick-up in growth and despite a still high public deficit tends to give credit to this idea. 
Figure 3. Calibration of the interest rate spreads' distribution as a function of public debt dynamics and market confidence ${ }^{1}$

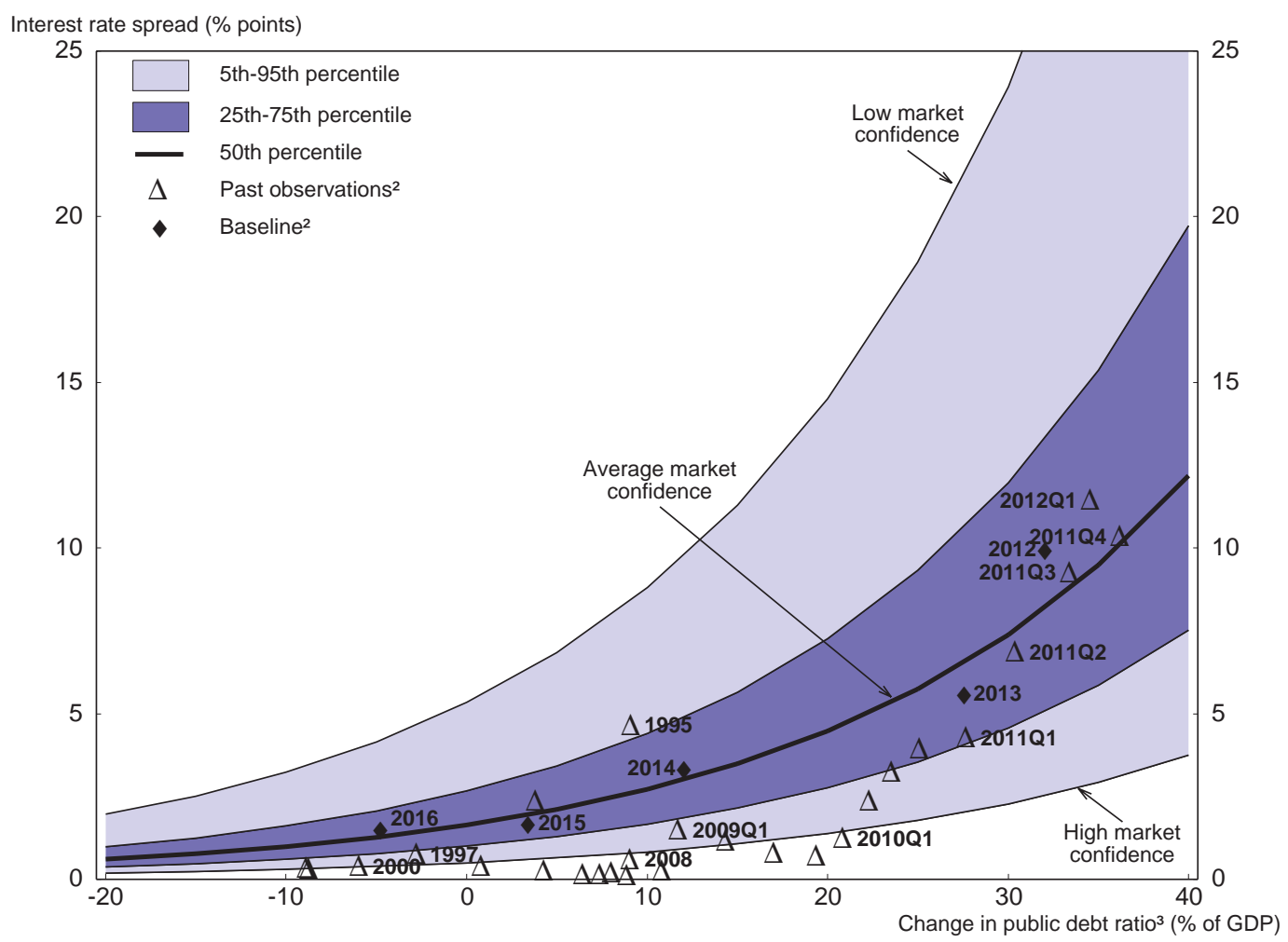

1. For a given change in the public debt ratio, the spread (between Portuguese and German bond yields) is assumed to be distributed with the probabilities presented in the figure depending on a random parameter representing market confidence. For example, if the public debt ratio has been rising by $10 \%$ of GDP over the past three years, the spread is drawn randomly with a $90 \%$ chance of being between $0.8 \%$ (5th percentile) and $8.8 \%$ (95th percentile).

2. For past observations: annual data from 1995 to 2008 , quarterly data from 2009 onwards. For the baseline: annual data for 2012 to 2016.

3. Cumulated change over the three preceding years.

Interest payments on public debt (INT, expressed in EUR billion) reflect the evolution of market interest rates, taking into account that outstanding debt is only rolled over progressively and that the EUIMF programme currently provides funds at a much cheaper rate than the market would. Interest payments are broken down as the sum of interest on the (still existing) short-term debt emission programme $\left(\right.$ Debt_ST $T_{t}$ ), outstanding long-term bonds and EU-IMF programme loans (Debt_prog) (equation 6, Table 2). The interest rate on short-term bills (IRS) is assumed to be a third of the long-term rate (IRL), a relatively simple assumption roughly consistent with observations over the last few quarters. The interest rate on programme funds is assumed to follow the risk-free interest rate plus a constant spread of 100 basis points.

$$
I N T_{t}=\text { Debt_ST }_{t} \times I R S_{t}+\sum_{i<t} \text { Outstanding_LTbonds } s_{i} \times I R L_{i}+D e b t_{-} p r o g_{t} \times I R_{-} p r o g_{t}
$$


Table 2. Portugal's government main sources of financing in the baseline scenario

Billion Euros

\begin{tabular}{lccc}
\hline Short-term debt emissions & $\begin{array}{c}\text { Medium and long-term debt } \\
\text { emissions }\end{array}$ & $\begin{array}{c}\text { EU-IMF programme loans } \\
\text { (annual inflows) }\end{array}$ \\
\hline 2011 & 17.8 & 11.2 & 35.3 \\
2012 & 18.3 & 0.0 & 26.9 \\
2013 & 17.2 & 9.7 & 9.8 \\
2014 & 15.2 & 13.8 & 7.8 \\
2015 & 15.2 & 16.6 & 0.0 \\
2016 & 16.4 & 26.9 & 0.0 \\
\hline
\end{tabular}

Source: IMF (2012), "Portugal: Third Review Under the Extended Agreement”, International Monetary Fund, April.

The disbursement of programme funds and the short- and long-term emission programmes are assumed to go as planned under the programme, with the first long-term bonds emissions scheduled by the end of 2013 (IMF, 2012). The redemption schedule of outstanding bonds - as anticipated in IMF (2012) is also taken into account. Additional emission needs arising from higher public deficits than in the programme are assumed to be financed exclusively through new long-term bonds at market interest rates ${ }^{9}$. In the main set of results, EU-IMF financing is not expected to be extended beyond 2013. However, an alternative specification is also presented in which (relatively cheap) programme financing is extended if needed as long as nominal deficit targets of the programme are met.

Finally, a number of accounting identities link the different variables:

- The accumulation of public debt is derived from the stock-flow identity $P D e b t_{t}=\frac{P^{2} e b t_{t-1}}{\left(1+g_{t}\right)\left(1+p_{t}\right)}-$ $N L G_{t}+\overline{S F A_{t}}$, where $\overline{S F A_{t}}$ corresponds to the (exogenous) stock-flow adjustments projected in the programme, expressed as a share of GDP (European Commission, 2012) ${ }^{10}$. These adjustments notably result from privatisation proceeds directed to debt reduction (with no impact on the deficit) and from time lags between the reception of programme funds and their utilisation;

- The evolution of the output gap (GAP) depends on the difference between actual and potential growth: $G A P_{t}=G A P_{t-1}+g_{t}-g_{-} p o t_{t}$. Potential growth $\left(g_{-} p o t_{t}\right)$ is exogenous, a simplifying assumption, which does not take into account that hysteresis effects could affect potential growth in simulation paths featuring very deep recessions (DeLong and Summers, 2012). However, these would have relatively little effect on actual output over the relatively short projection horizon considered in this paper (2012-16);

9. Symmetrically, in case of over-performance of deficit targets, long-term debt emissions are assumed to be reduced accordingly. If this results in negative emission needs, the assumption is made that extra funds available are used to buy back bonds at the market interest rate (which is equivalent to "negative" emissions).

10. The government forecasts somewhat lower stock-flow adjustments for 2014-16 (Portuguese Authorities, 2012). Using the government's assumption instead of the European Commission's one would lower the projected public debt ratio by $3 \%$ of GDP by 2016 . 
- The government net lending $(N L G)$ corresponds to the primary balance plus the cost of interest payments (as a share of GDP): $N L G_{t}=N L G X_{t}-\frac{I N T_{t}}{G D P_{t}}$. The structural balance $(N L G U)$ is the net lending adjusted for cyclical fluctuations and one-offs, with the automatic stabilisers as a share of GDP calibrated at 0.46 (Girouard and André, 2005): $N L G U_{t}=N L G_{t}-0.46 G A P_{t}$. Finally, the structural primary balance $(N L G X U)$ is the structural balance excluding interest payments: $N L G X U_{t}=N L G U_{t}+\frac{I N T_{t}}{G D P_{t}}$.

Two different fiscal policy strategies are envisaged: sticking to the programme's nominal deficit targets ( $\overline{N L G_{-} \text {targets }}$ ) and letting automatic stabilisers play, i.e. sticking to the primary structural deficit targets implied by the programme $(\overline{N L G X U})$. The latter strategy means implementing the consolidation measures underlying the programme path without compensating for the effect of surprises in terms of GDP growth or interest payments ${ }^{11}$.

- $\quad N L G_{t}=\overline{N L G_{-} \text {targets }_{t}}$

- $\quad N L G X U_{t}=\overline{N L G X U_{t}}$

\section{The baseline scenario}

For 2012-13, the baseline scenario consists of projections from OECD Economic Outlook No 91 (Table 3). The only exception is long-term interest rates, where the (more favourable) assumptions from IMF (2012) are used, notably because they appear more consistent with the calibration of spreads presented in Figure $3^{12}$. Consistent with OECD projections, the public deficit in the baseline scenario is $3.5 \%$ of GDP in 2013 , higher than the $3.0 \%$ targeted by the authorities, as a result of lower GDP growth than forecast by the authorities. Consequently, in the "nominal targets" strategy (FP1), additional consolidation measures are assumed to be taken to meet the $3.0 \%$ target, which notably reduces growth (equation 1). In contrast, no additional action is taken in the "automatic stabilisers" strategy (FP2).

For 2014-16, the baseline scenario is extended with the economic scenario underlying the EU-IMF programme (IMF, 2012), while the pace of fiscal consolidation is assumed to follow the plans presented by the Portuguese authorities in May 2012 (Portuguese Government, 2012), albeit with a higher starting point in terms of the 2013 deficit. These new plans are more ambitious than plans presented in IMF (2012), but despite this more rapid consolidation, growth in the baseline scenario is assumed to remain as in IMF (2012), around $2 \%$ per year over 2014-16.

11. Hybrid policy strategies have also been tested, with a different reaction depending on the sign of shocks. For example, a strategy consists of sticking to nominal deficit targets in case of positive shocks, but letting automatic stabilisers play in case of negative shocks. Consistently with intuition, this strategy yields broadly similar results to FP2 for the upper part (i.e. above the $50^{\text {th }}$ percentile) of the results figures for unemployment and public debt, but results closer to FP1 for their lower part. The symmetric option (always choosing the most ambitious option between FP1 and FP2) yields symmetric results.

12. The projections from the Economic Outlook No. 91 rely on the technical assumption that interest rate spreads vis-à-vis Germany remain constant over 2012-13, which does not directly take into account public finance developments over the period. 
Table 3. Main assumptions underlying the baseline scenario

\begin{tabular}{|c|c|c|c|c|c|c|c|c|c|}
\hline & $\begin{array}{c}\text { Real } \\
\text { GDP } \\
\text { growth }\end{array}$ & $\begin{array}{l}\text { Potential } \\
\text { GDP } \\
\text { growth }\end{array}$ & $\begin{array}{l}\text { Inflation } \\
\text { (GDP } \\
\text { deflator) }\end{array}$ & $\begin{array}{l}\text { Unemploy- } \\
\text { ment rate }\end{array}$ & $\begin{array}{c}\text { Interest rate } \\
\text { on } \\
\text { Portuguese } \\
\text { bonds }\end{array}$ & $\begin{array}{l}\text { Public } \\
\text { balance }\end{array}$ & $\begin{array}{c}\text { Public } \\
\text { balance: } \\
\text { authorities' } \\
\text { targets }\end{array}$ & $\begin{array}{l}\text { Structural } \\
\text { primary } \\
\text { balance }\end{array}$ & $\begin{array}{c}\text { Public } \\
\text { debt }\end{array}$ \\
\hline & g & g_pot & $p$ & UNR & IRL & NLG & NLG_targets & NLGXU & PDebt \\
\hline & $\%$ & $\%$ & $\%$ & $\%$ & $\%$ & $\begin{array}{l}\% \text { of } \\
\text { GDP }\end{array}$ & $\%$ of GDP & $\begin{array}{c}\% \text { of potential } \\
\text { GDP }\end{array}$ & $\begin{array}{l}\% \text { of } \\
\text { GDP }\end{array}$ \\
\hline 2010 & 1.4 & 0.4 & 1.1 & 10.8 & 5.4 & -9.8 & - & -5.1 & 93.4 \\
\hline 2011 & -1.6 & -0.4 & 0.7 & 12.8 & 10.2 & -4.2 & - & -2.2 & 107.8 \\
\hline 2012 & -3.2 & 0.3 & 0.1 & 15.4 & 11.7 & -4.6 & -4.5 & 1.5 & 114.5 \\
\hline 2013 & -0.9 & 0.3 & 0.4 & 16.2 & 8.0 & -3.5 & -3.0 & 3.5 & 120.3 \\
\hline 2014 & 2.1 & 0.1 & 1.3 & 15.4 & 6.3 & -2.3 & -1.8 & 4.0 & 119.2 \\
\hline 2015 & 1.9 & 0.4 & 1.4 & 14.6 & 5.0 & -1.5 & -1.0 & 4.0 & 117.3 \\
\hline 2016 & 1.9 & 0.6 & 1.6 & 13.9 & 5.1 & -1.0 & -0.5 & 4.0 & 114.9 \\
\hline
\end{tabular}

Source: OECD (2012), OECD Economic Outlook: Statistics and Projections (database), May; IMF (2012), "Portugal: Third Review Under the Extended Agreement", International Monetary Fund, April; and Ministry of Finance (2012), Documento de Estratégia Orçamental 2012-2016.

\section{Calibration and properties of the shocks}

In the projection period, random shocks directly affect GDP growth, inflation, the unemployment rate and the ("risk-free") interest rate on German bonds. In addition, market confidence, which influences the interest rate spread, is also a random parameter. All these shocks then affect the path of other variables via the model. The magnitude of shocks in 2012 is assumed to be half that of shocks in subsequent years, reflecting relatively less uncertainty as some data concerning the first half of the year are already available and as uncertainty surrounding macroeconomic forecasts increases with the horizon.

Shocks are calibrated using the residuals of equations (1) to (4), for consistency with the projection framework. Their standard deviation and cross-correlation are presented respectively in Tables 4 and 5 . Only two pairs of shocks exhibit significant cross-correlation. Shocks affecting GDP growth are positively correlated with price shocks, consistently with the idea that positive demand shocks are generally associated with higher prices. Secondly, GDP growth shocks are positively correlated with shocks to the interest rate on German bonds, which can be interpreted as reflecting the reaction of (current and anticipated) monetary policy to demand shocks in the euro zone, which also affect Portugal. In contrast, the correlation between growth shocks and unemployment shocks is close to zero. This is because the effect of growth on unemployment is already accounted for in equation (3), meaning that unemployment shocks only consist of non growth-related shocks, such as labour force shocks.

Table 4. Standard deviation of shocks

Estimated over 1995-2011, per cent

\begin{tabular}{lcccc}
\hline & GDP growth & Inflation & Unemployment rate & $\begin{array}{c}\text { Interest rate on } \\
\text { German bonds }\end{array}$ \\
\hline Standard deviation & 1.9 & 0.6 & 0.5 & 0.5 \\
\hline
\end{tabular}

1. Standard deviation of shocks for 2012 is assumed to be half this, reflecting less uncertainty as some data concerning the first half of the year are already available. 
Table 5. Cross correlation of shocks

Estimated over 1995-2011

\begin{tabular}{lcccc}
\hline & GDP growth & Inflation & Unemployment rate & $\begin{array}{c}\text { Interest rate on } \\
\text { German bonds }\end{array}$ \\
\hline GDP growth & 1 & - & - & - \\
Inflation & 0.5 & 1 & - & - \\
Unemployment rate & 0.1 & 0.0 & 1 & - \\
Risk-free interest rate & 0.4 & 0.0 & 0.0 & 1 \\
\hline
\end{tabular}

\section{Monte Carlo procedure and simulations}

Simulations are run 10000 times in a Monte Carlo procedure. For each simulation and each year, a set of shocks and a market confidence parameter are drawn randomly and fed into the model along with a fiscal policy strategy. As variables are endogenous (e.g. growth depends on fiscal policy, which depends on growth), a number of iterations are necessary to ensure convergence of projections for each year in each Monte Carlo simulation. Ten iterations were sufficient in almost all cases.

As explained earlier, the model is run in terms of deviations from the baseline scenario presented in Table 3. This means that alternative forms of equations (1) to (4) are used for projections, which are expressed in terms of deviations from the baseline. These alternative forms are numbered (1bis) to (4bis) and defined as $(\mathrm{Xbis})=(\mathrm{X})-(\overline{\mathrm{X}})$, where $\overline{\mathrm{x}}$ represents the value of the variable $\mathrm{x}$ in the baseline scenario. Shocks are denoted $\varepsilon_{X, t}$. Accounting identities do not need modification as they are valid both in the baseline scenario and all other possible projection paths.

$$
\begin{gathered}
g_{t}-\overline{g_{t}}=g_{-} p o t_{t}-\overline{g_{-} p o t_{t}}-0.20\left(G A P_{t-1}-\overline{G A P_{t-1}}\right)-0.33\left[\Delta\left(I R L_{t-1}-p_{t-1}\right)-\Delta\left(\overline{I R L_{t-1}}-\overline{p_{t-1}}\right)\right] \\
\left.-0.67\left(\Delta N L G X_{t}-\overline{\Delta N L G X_{t}}\right)-0.33\left(\Delta N L G X_{t-1}-\overline{\Delta N L G X_{t-1}}\right)+\varepsilon_{g, t} \quad \text { (1bis }\right) \\
p_{t}-\overline{p_{t}}=0.46\left(p_{t-1}-\overline{p_{t-1}}\right)+0.19\left(G A P_{t-1}-\overline{G A P_{t-1}}\right)+\varepsilon_{p, t} \quad \text { (2bis) } \\
\left.\Delta U N R_{t}-\Delta \overline{U N R_{t}}=-0.27\left(g_{t}-\overline{g_{t}}\right)-0.14\left(g_{t-1}-\overline{g_{t-1}}\right)+\varepsilon_{U N R, t} \quad \text { (3bis }\right) \\
\left.\Delta I R L_{-} G e r_{t}-\Delta \overline{I R L_{-} G e r_{t}}=\varepsilon_{I R L_{-} G e r, t} \quad \text { (4bis }\right)
\end{gathered}
$$

\section{Simulation results}

Results are presented respectively in Figures 4 and 5 for the two fiscal policy strategies: sticking to nominal deficit targets and letting automatic stabilisers play. In both cases, uncertainty about growth and interest rates developments is relatively high (although somewhat decreasing with time as the fiscal position improves), meaning that meeting nominal deficit targets can in certain cases require a large amount of additional consolidation measures. This is illustrated by the probabilities associated with the different structural primary balance paths in the "nominal targets" strategy. The effect of these additional consolidation measures is to amplify growth shocks, resulting in significantly higher amplitude of GDP growth deviations in the "nominal targets" fiscal strategy than in the "automatic stabilisers" one. In turn, this larger risk of a deeper recession in the "nominal targets" strategy is reflected in unemployment paths, with a potentially higher peak in the unemployment rate, and in inflation developments, with possible stronger disinflation, or even deflation. 
Figure 4. Sticking to nominal deficit targets

Per cent

25th-75th percentile
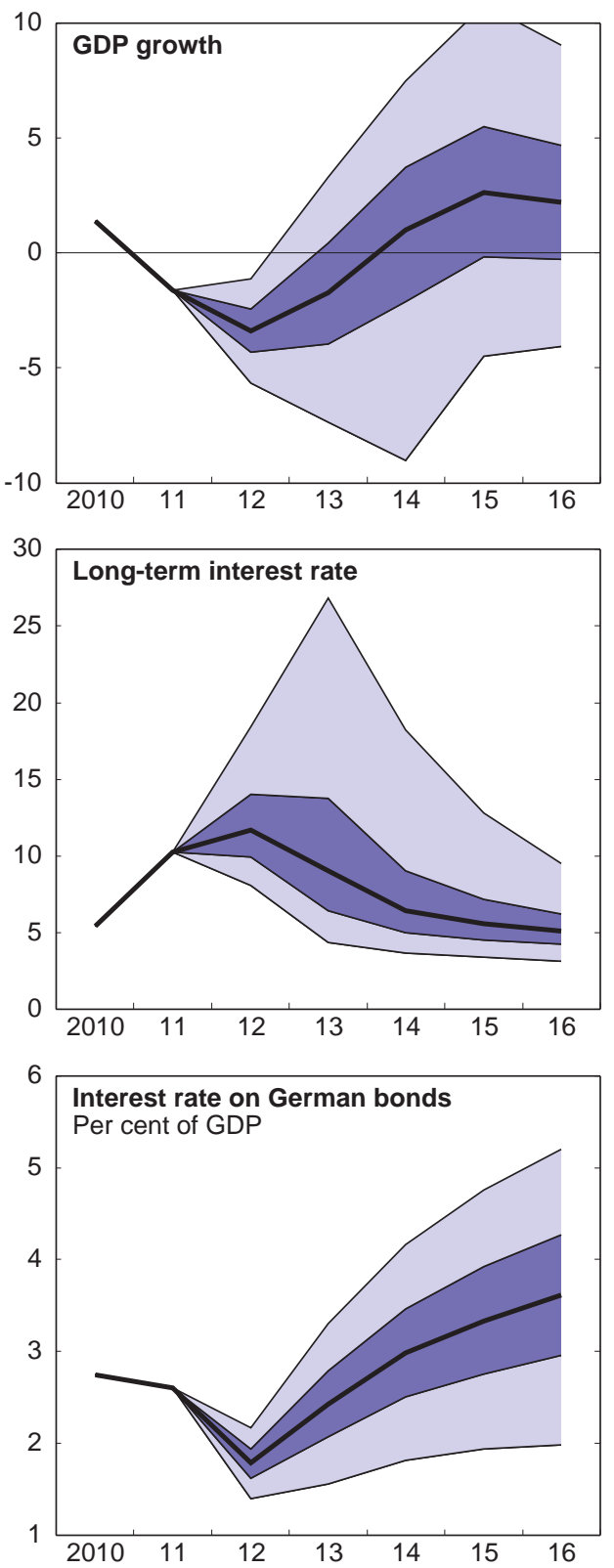

5th-95th percentile $\quad$ 50th percentile
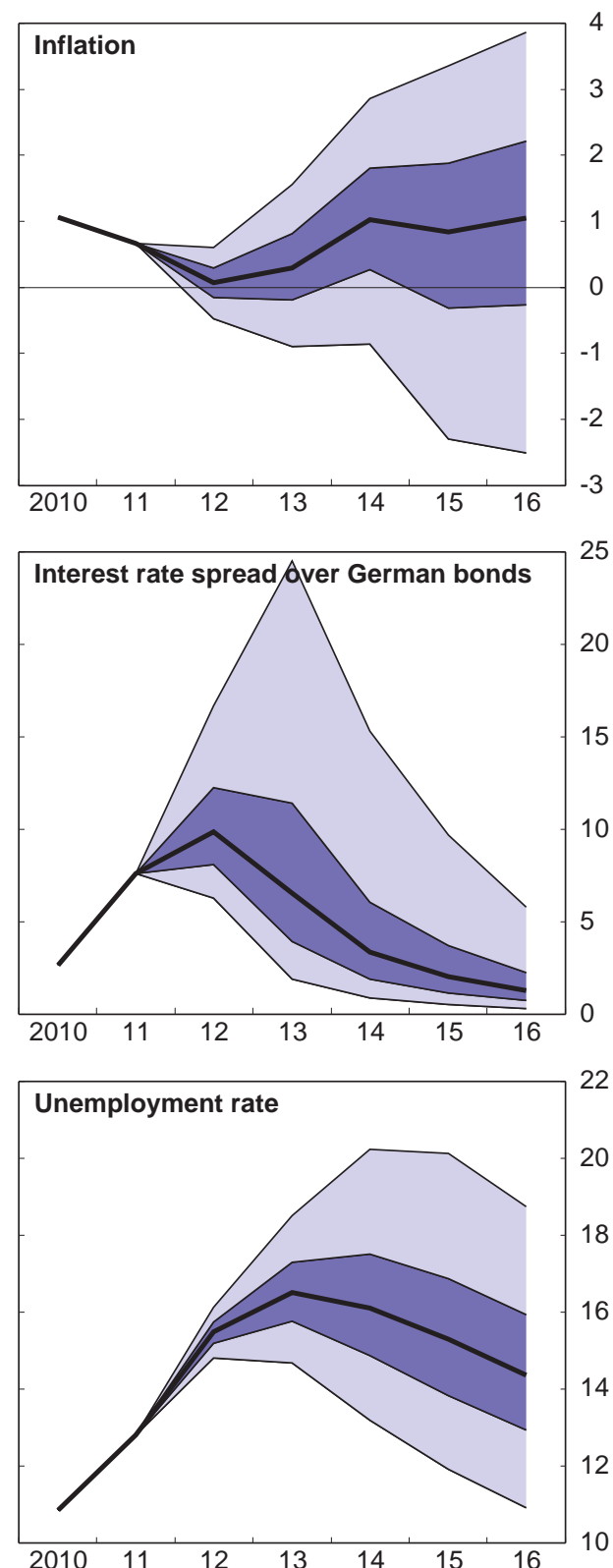
Figure 4. Sticking to nominal deficit targets (continued)

Per cent of GDP ${ }^{1}$

25th-75th percentile
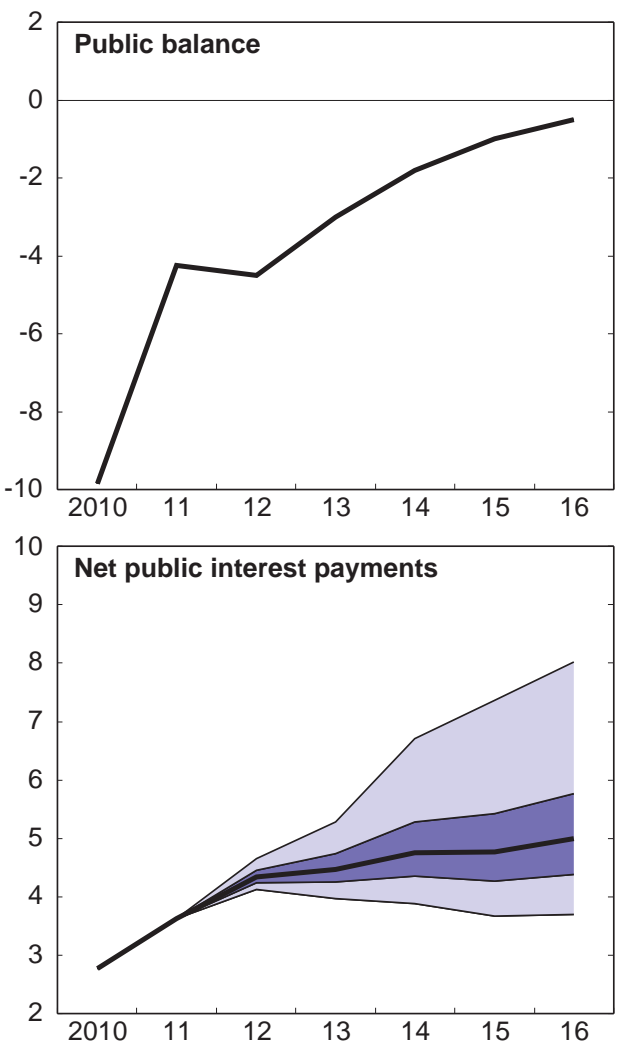

5th-95th percentile $\quad$ 50th percentile
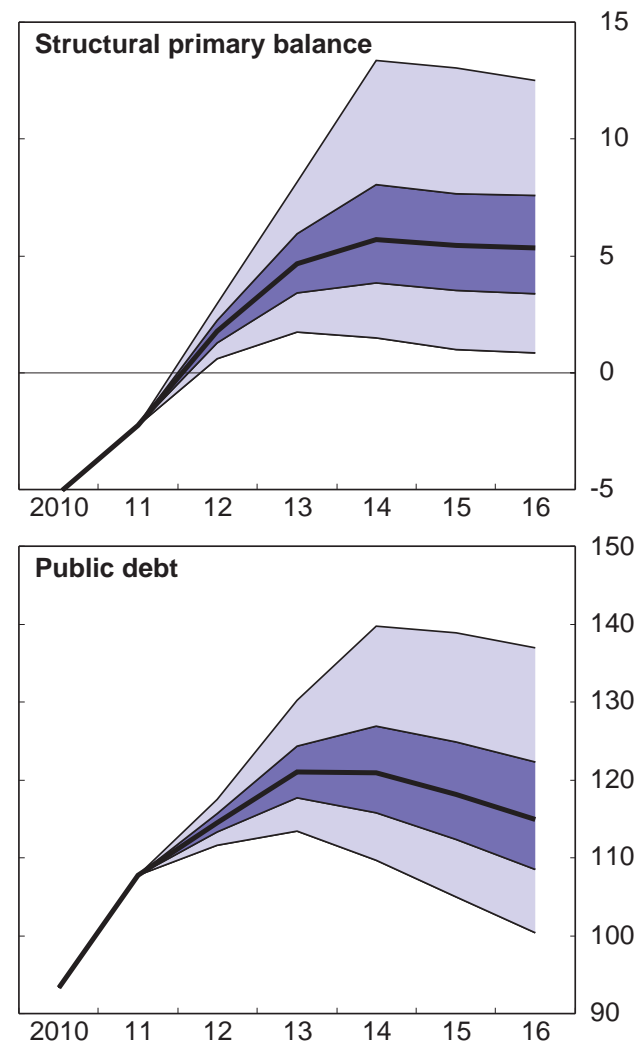

1. Per cent of potential GDP for the structural primary balance.

In terms of public debt developments, the two strategies yield broadly similar results until 2014, but for different reasons, which explains diverging trends after 2014. In the "nominal targets" strategy, the public debt ratio differs from the baseline only due to different nominal GDP growth, because the nominal public deficits are fixed. Thus, the realisations of high debt ratios in Figure 4 correspond to situations of a low deficit but lower growth. In contrast, in the "automatic stabilisers" strategy, the fluctuations of nominal GDP growth are narrower, both in terms of volume and price, but the public deficit is allowed to differ from the baseline, meaning that the situations of high debt ratios are also situations of high deficit. This explains the divergence in debt trends after 2014, which are clearly more favourable in the "nominal targets" strategy. Indeed, in this strategy, activity is expected to rebound after a large contraction, while, in the "automatic stabilisers" strategy, deficits would remain high as no additional consolidation measures are assumed, leading to further increases in public debt.

To sum up, both strategies considered would in most cases result in sustainable debt dynamics, but there is a trade-off regarding the risks implied. Relative to the "automatic stabilisers" strategy, the "nominal targets" strategy brings more certainty in terms of debt decline and lower interest rates in the medium-term, but at the risk of a deeper recession in 2013-14, reflected in higher unemployment and declining prices. 
Figure 5. Letting automatic stabilisers play (respecting primary structural deficit targets)

Per cent

25th-75th percentile
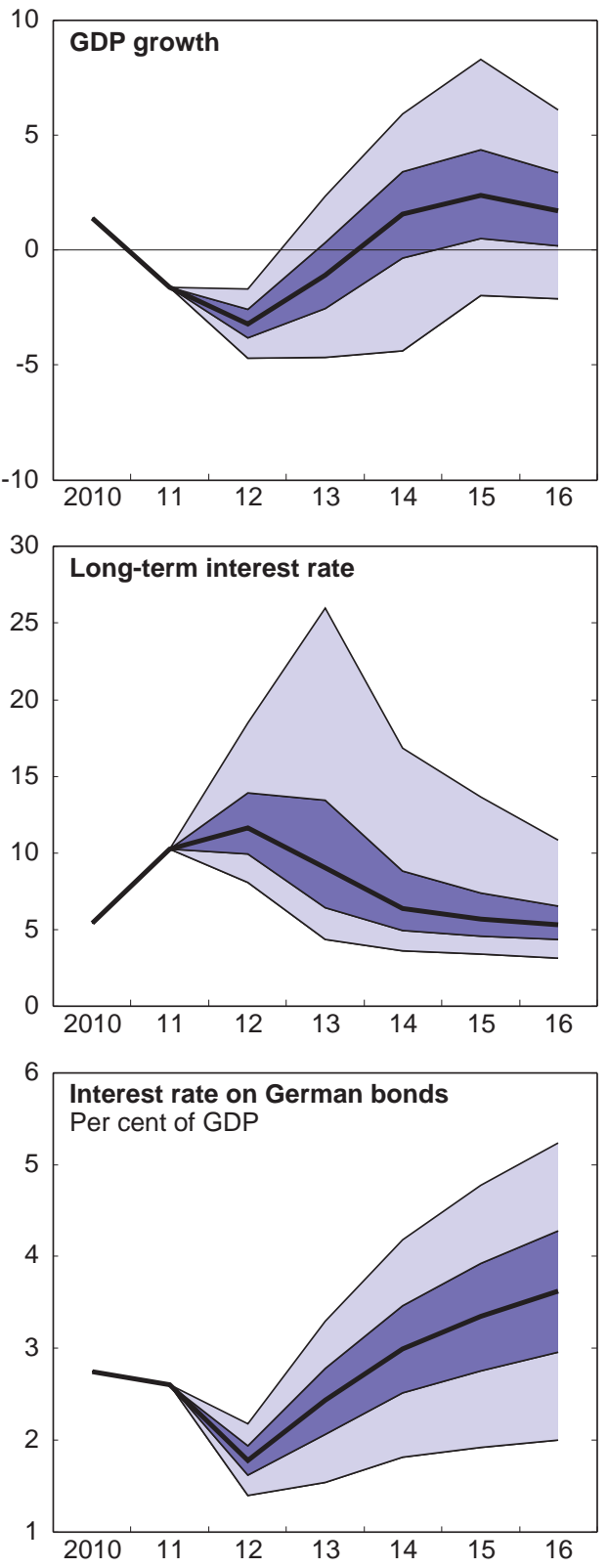

5th-95th percentile — 50th percentile
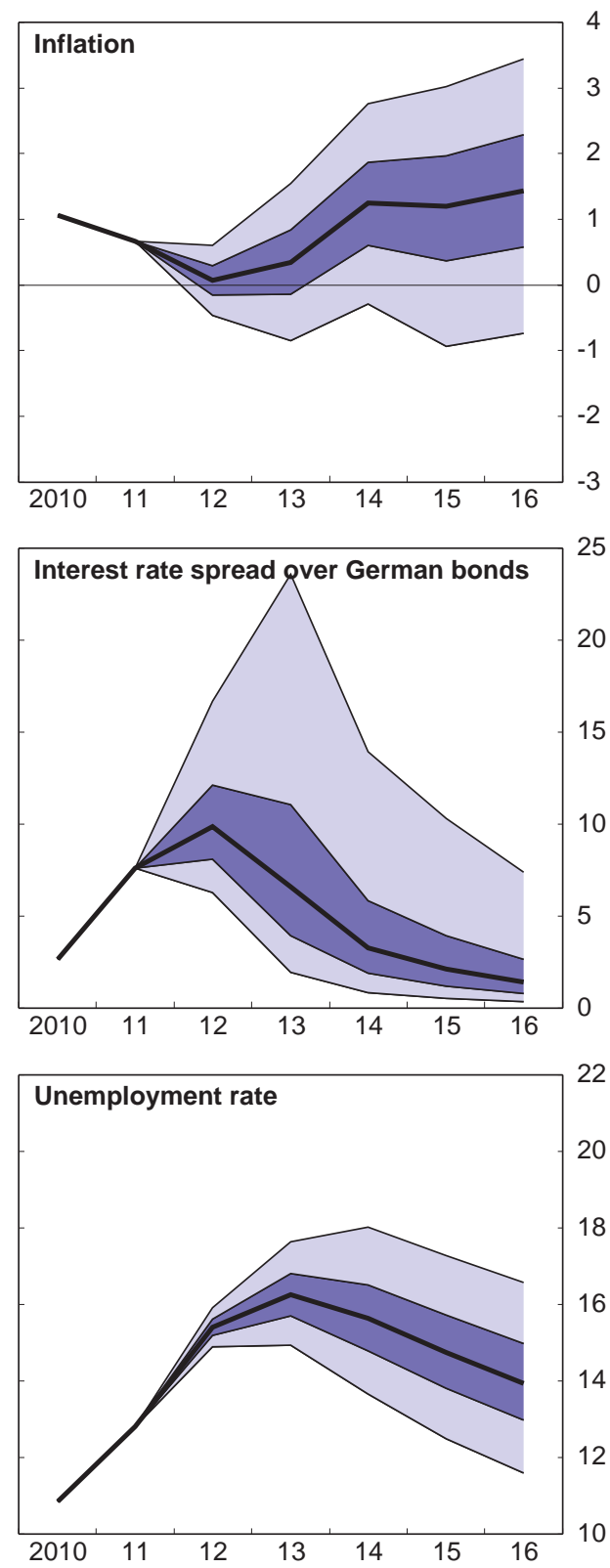
ECO/WKP(2012)61

Figure 5. Letting automatic stabilisers play (respecting primary structural deficit targets) (continued)

Per cent of GDP ${ }^{1}$

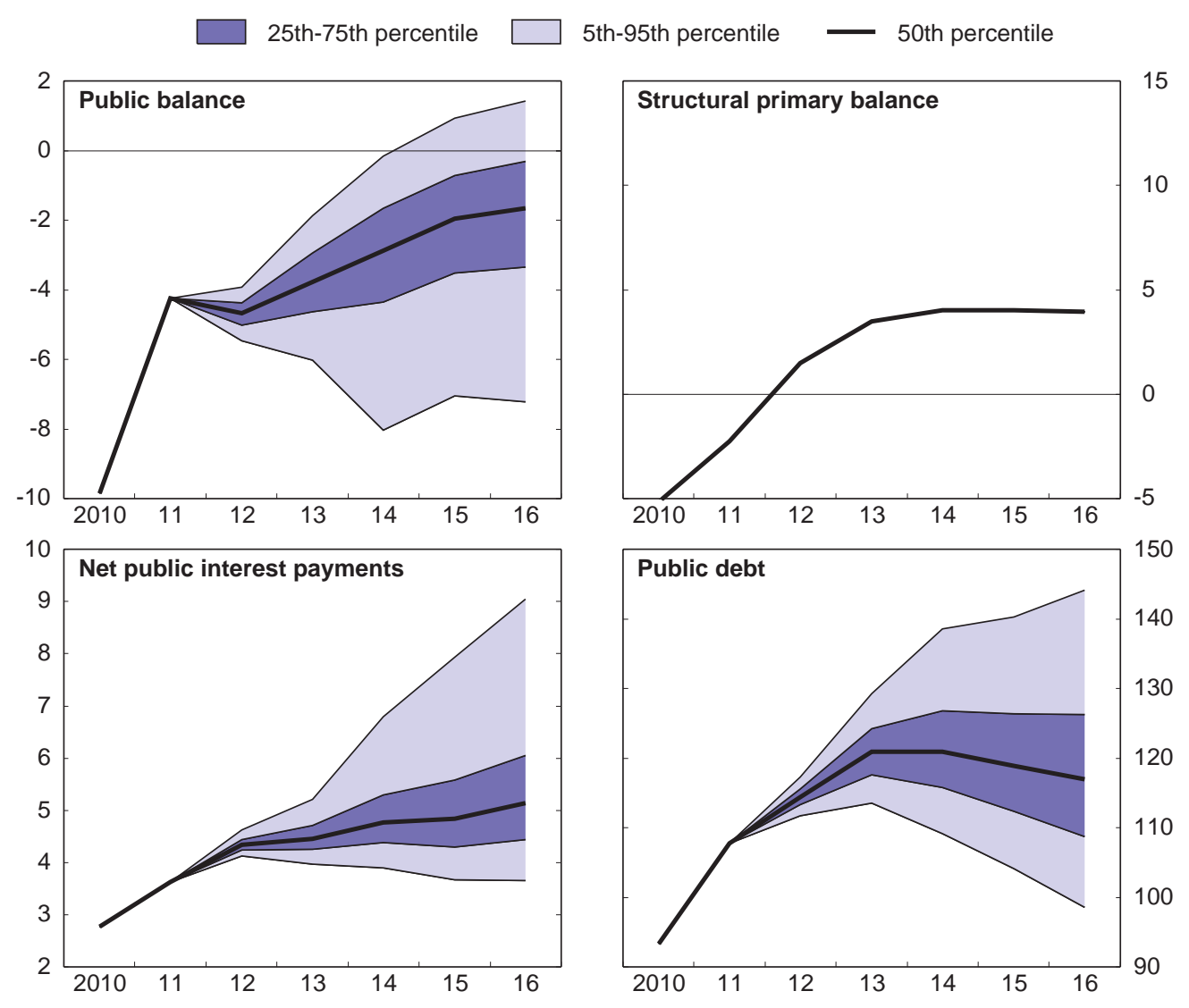

1. Per cent of potential GDP for the structural primary balance.

\section{Results under alternative assumptions}

The results are sensitive to a number of assumptions, some of which can be influenced by government policy. To illustrate this sensitivity, we present a simplified set of results with alternative assumptions regarding: the fiscal multiplier, potential growth and the potential extension of EU-IMF financing. 


\section{Sensitivity to the fiscal multiplier}

Simulation results obtained with fiscal multiplier of respectively 0.5 and 1.5 are presented in Figures 6 and 7. The results suggest that the lower the multiplier, the lower the risk that sticking to nominal deficit targets will result in a deep recession and thus the more favourable this strategy appears. Indeed, with a multiplier of 0.5 , the difference between the two fiscal policy strategies in terms of unemployment is relatively limited, while the debt dynamics are clearly more favourable in the "nominal targets" strategy. On the contrary, with a multiplier of 1.5, sticking to nominal deficit targets runs a larger risk of a deep recession and a downward spiral of austerity and recession.

Figure 6. Sensitivity analysis: Fiscal multiplier of 0.5 (instead of 1)

25th-75th percentile

A. Respecting the nominal deficit targets

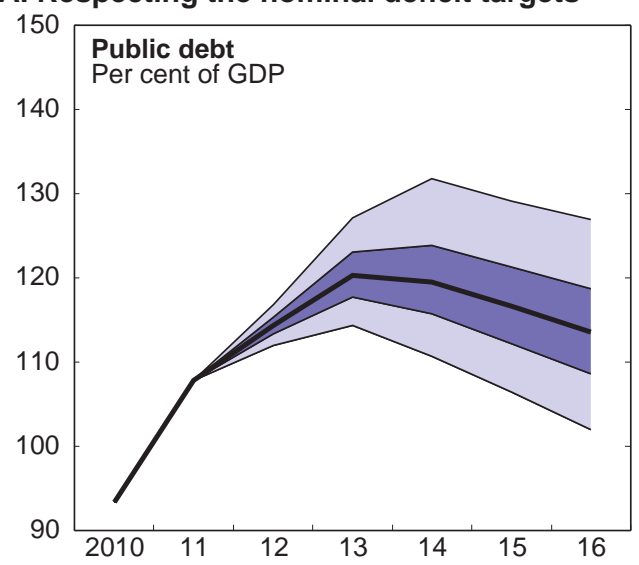

B. Letting automatic stabilisers play ${ }^{1}$

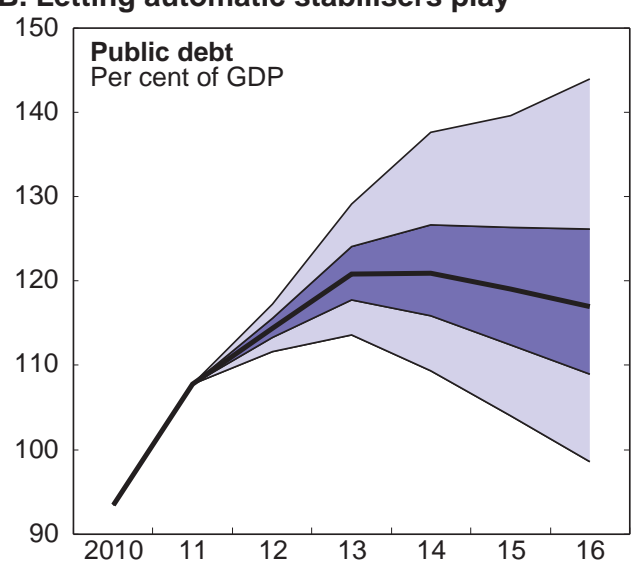

5th-95th percentile $\quad$ 50th percentile
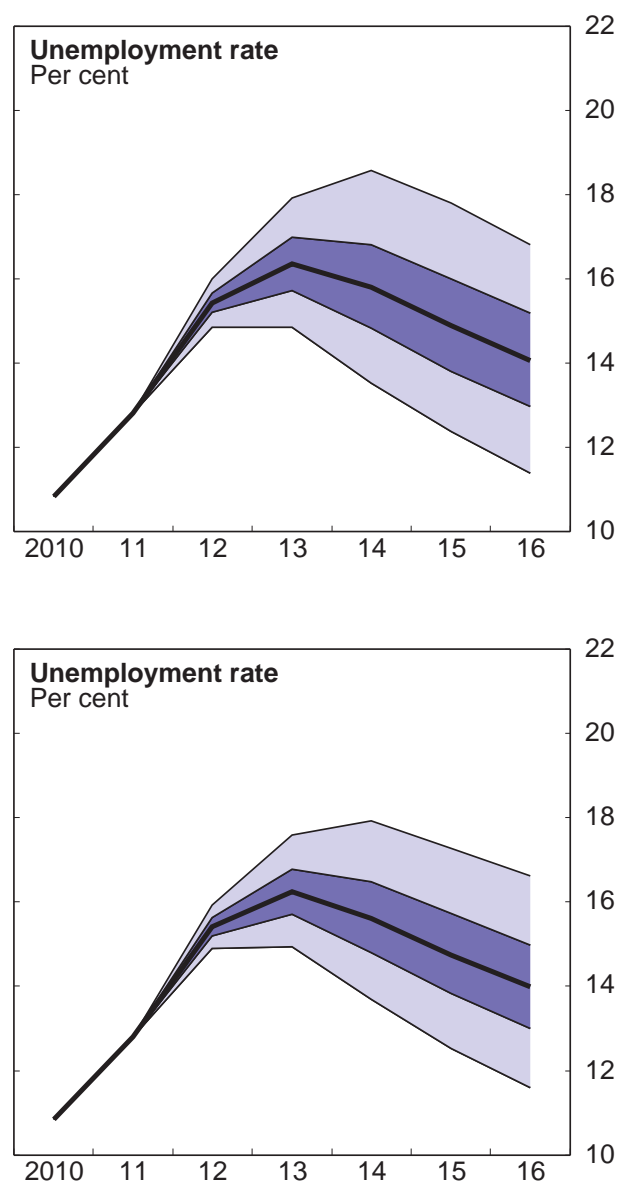

1. Respecting the structural primary deficit targets. 
Figure 7. Sensitivity analysis: Fiscal multiplier of 1.5 (instead of 1)

25th-75th percentile

A. Respecting the nominal deficit targets

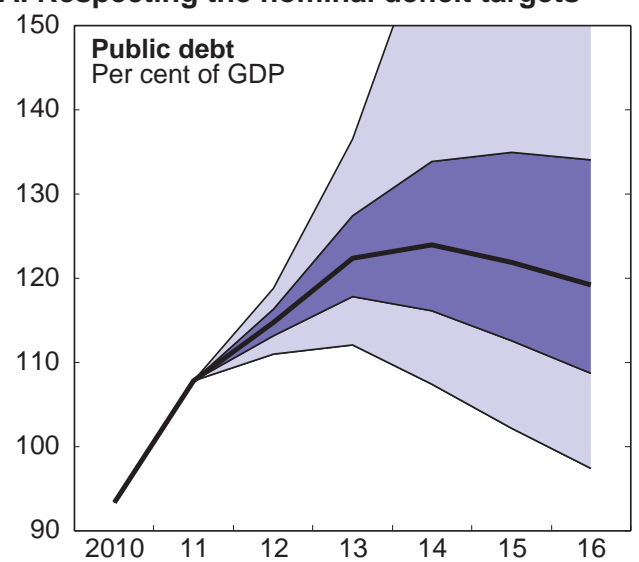

B. Letting automatic stabilisers play ${ }^{1}$

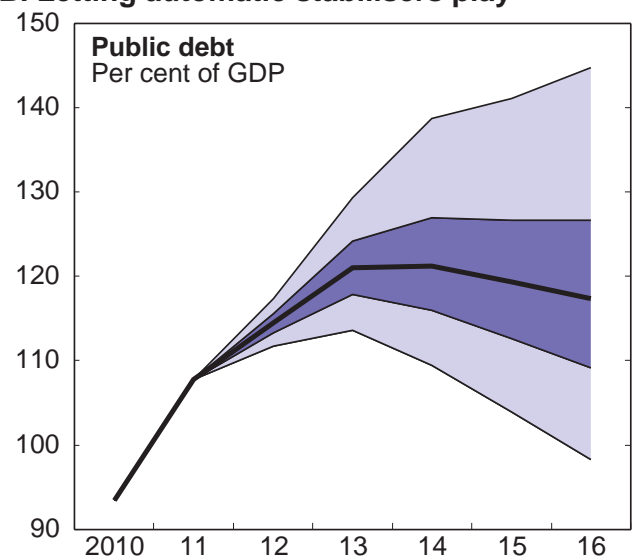

5th-95th percentile $\quad$ 50th percentile
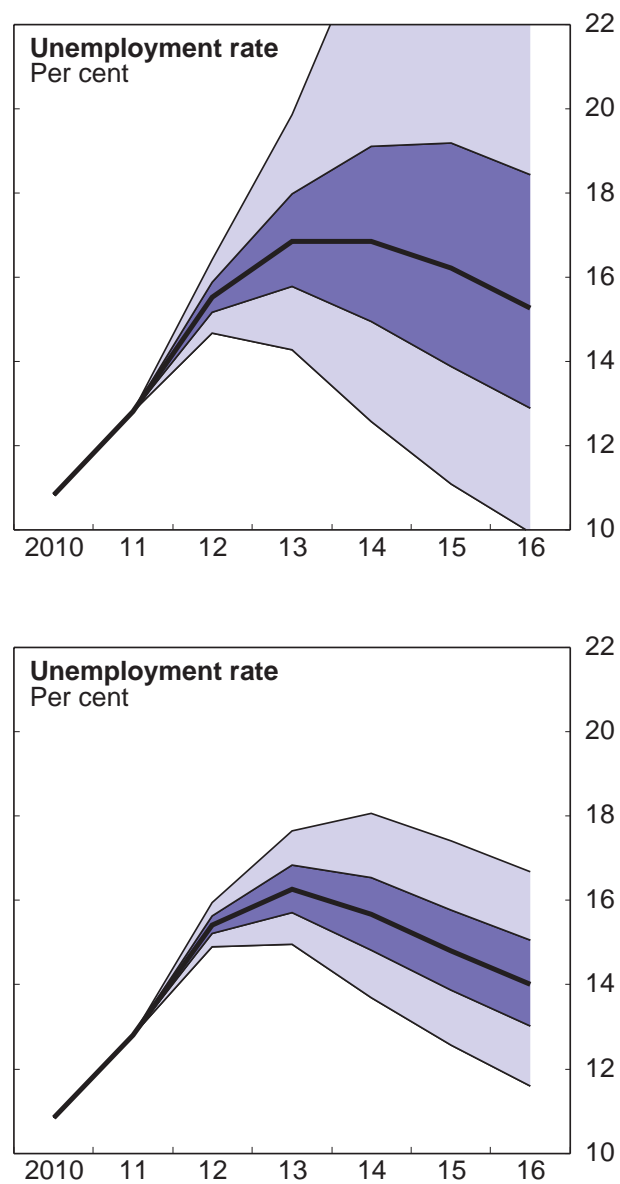

1. Respecting the structural primary deficit targets.

\section{Sensitivity to potential growth}

Potential growth in the baseline scenario averages $0.3 \%$ over 2012-16. However, potential growth could be higher if effective structural reforms are implemented rapidly. For example, Bouis and Duval (2011) estimate that broad reforms of product and labour market regulations as well as benefit, tax and retirement systems can, in Portugal, yield GDP gains of more than 5\% of GDP within 5 years. On the other hand, potential growth could also be lower than projected if not enough is done to prevent currently high unemployment from becoming structural. 
To illustrate possible effects of such structural policy changes, results obtained assuming potential growth of respectively $-0.5 \%$ and $+1.0 \%$ on average over 2012-16 are presented on Figures 8 and 9 . In the low potential growth scenario, public debt paths are less favourable for both fiscal policy strategies. The risks of high unemployment in the "nominal targets" strategy are also increased. On the contrary, higher potential growth makes it easier to respect fiscal targets as well as to regain control over public debt, while also keeping unemployment lower.

Figure 8. Sensitivity analysis: Average potential growth over $\mathbf{2 0 1 2 - 1 6}$ of $-0.5 \%$ (instead of $\mathbf{+ 0 . 3 \%}$ )

Note that this figure uses a different scale to other sensitivity analysis figures

25th-75th percentile

A. Respecting the nominal deficit targets

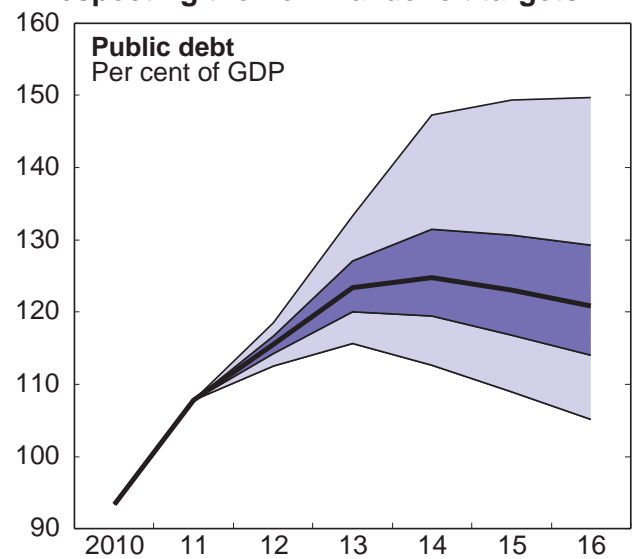

B. Letting automatic stabilisers play ${ }^{1}$

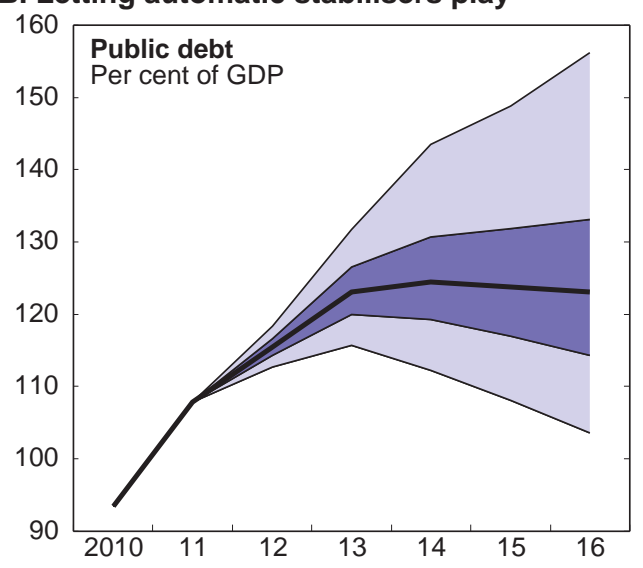

5th-95th percentile $\quad$ 50th percentile
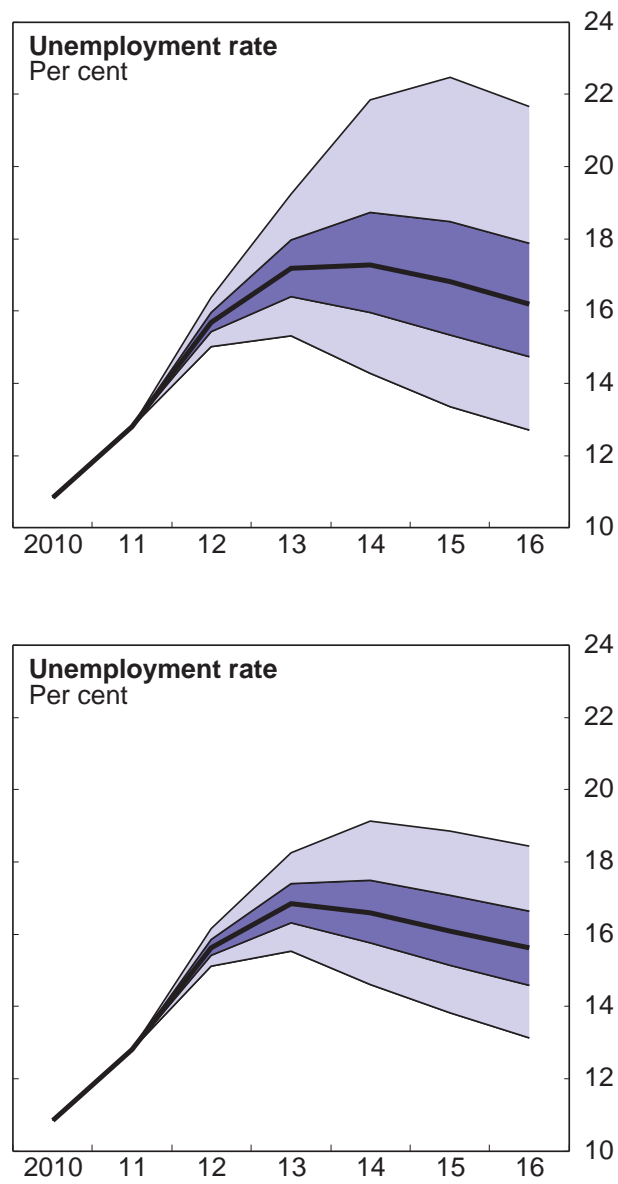

1. Respecting the structural primary deficit targets. 
Figure 9. Sensitivity analysis: Average potential growth over $2012-16$ of $+1.0 \%$ (instead of $+0.3 \%$ )

25th-75th percentile

A. Respecting the nominal deficit targets

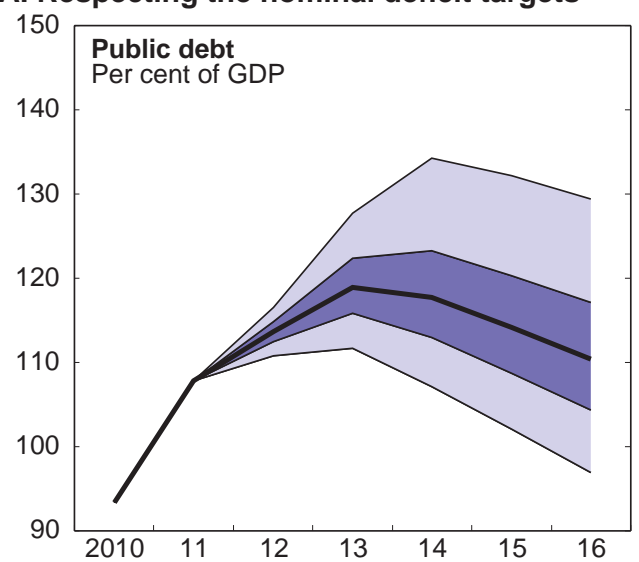

B. Letting automatic stabilisers play ${ }^{1}$

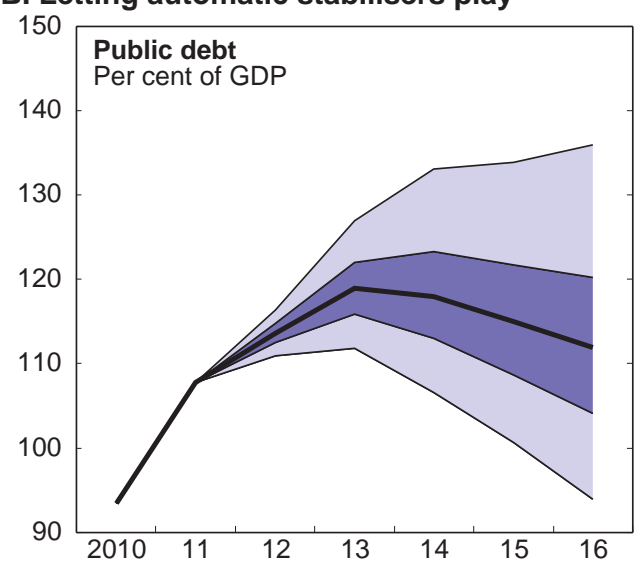

5th-95th percentile $\quad$ 50th percentile
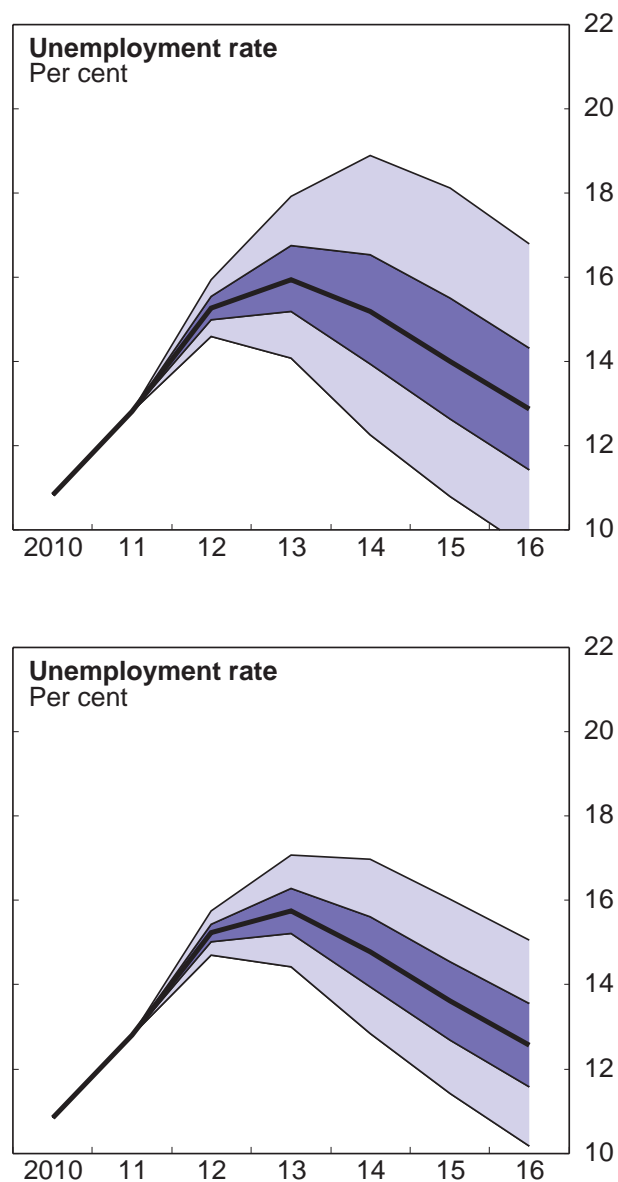

1. Respecting the structural primary deficit targets.

\section{Sensitivity to the extension of programme financing}

So far, the simulations have assumed no prolongation of the EU-IMF programme financing after the scheduled return to the markets in September 2013. As an alternative, Figure 10 presents the simulation results under the assumption that programme financing is extended if needed -i.e. as long as market interest rates are higher than the rate on programme funds - providing as nominal deficit targets are met (but not if nominal targets are missed). This implies a lower interest burden, especially in the "nominal targets" strategy where by definition nominal targets are met and programme financing can always be extended. This leads to slightly more favourable public debt and unemployment paths than in the main set of results. 
Figure 10. Sensitivity analysis: Programme financing extended after 2013 if nominal deficit targets are met

25th-75th percentile

A. Respecting the nominal deficit targets

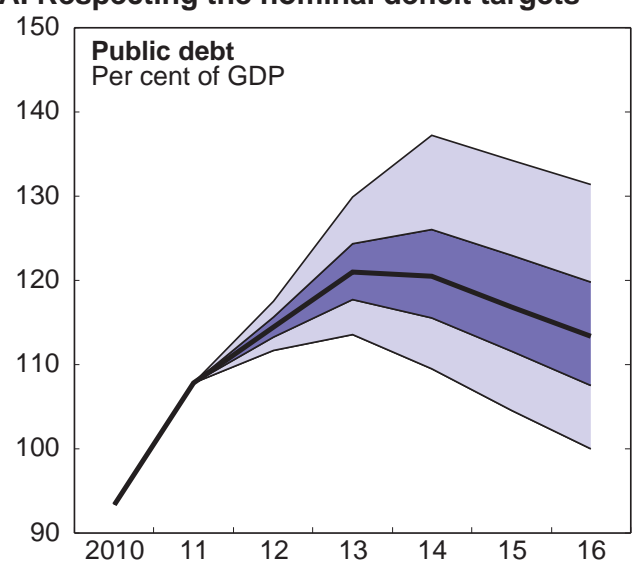

B. Letting automatic stabilisers play ${ }^{1}$

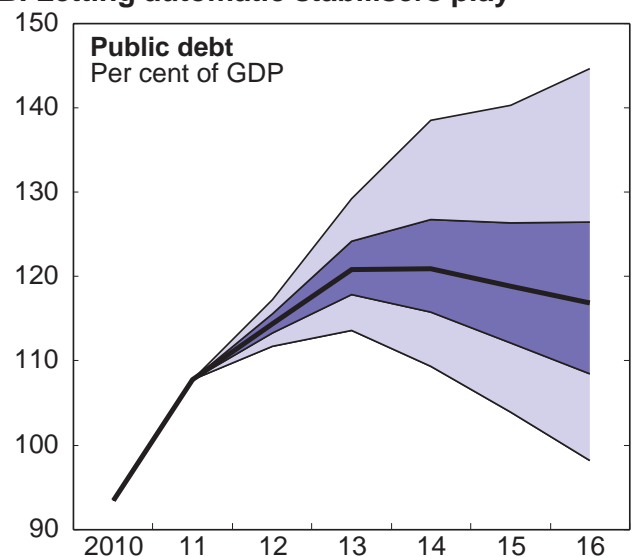

5th-95th percentile — 50th percentile
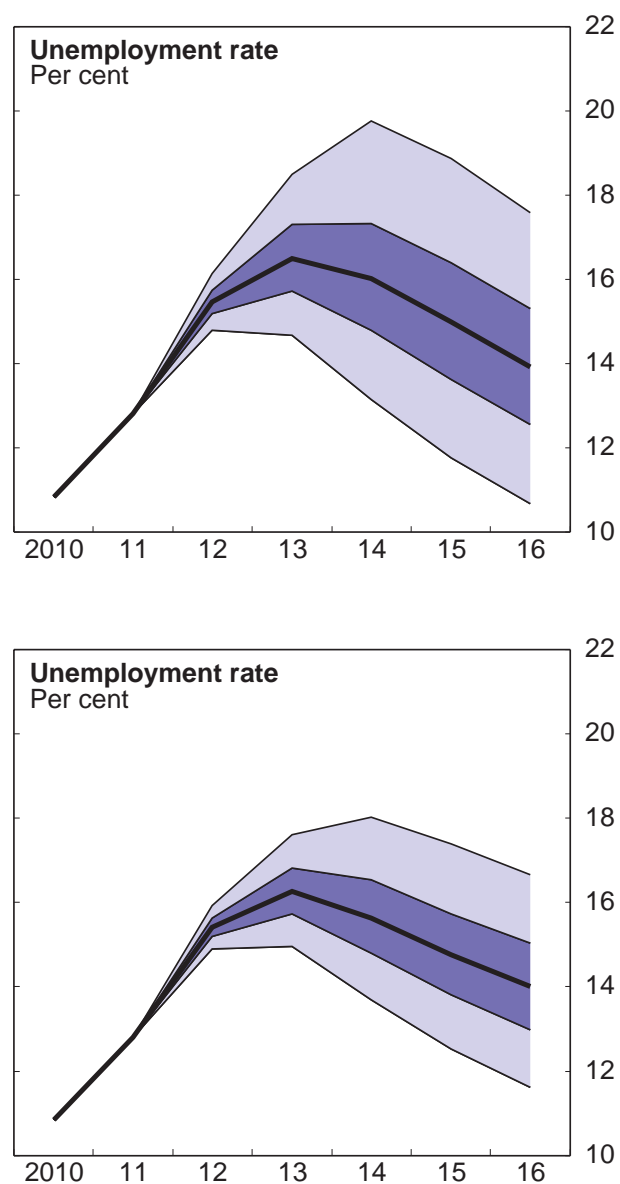

1. Respecting the structural primary deficit targets.

\section{Conclusion}

Under most assumptions tested, a clear trade-off appears between sticking to nominal deficit targets or letting automatic stabilisers play. Both strategies would in most cases allow regaining control over public debt dynamics, but both entail risks, albeit of a different nature. Sticking to nominal targets implies risks of high unemployment. In contrast, letting automatic stabilisers play implies risks of spiralling public debt and high interest rates. Sensitivity analyses show that under either fiscal policy strategy, these risks would be reduced if the fiscal consolidation instruments less damaging for growth are chosen and if potential growth is stimulated through structural reforms. 


\section{BIBLIOGRAPHY}

Almeida, V., G. Castro, R. Félix and J. Maria (2011), "Fiscal Policy in a Small Euro Area Country", Bank of Portugal Economic Bulletin, Spring.

Barrell, R., D. Holland and I. Hurst (2012), "Fiscal Consolidation: Part 2. Fiscal Multipliers and Fiscal Consolidations", OECD Economics Department Working Papers, No. 933, OECD Publishing.

Beynet, P. and E. Paviot (2012), "Assessing the sensitivity of Hungarian debt sustainability to macroeconomic shocks under two fiscal policy reactions", OECD Economics Department Working Papers, No. 946, OECD Publishing.

Bouis, R. and R. Duval (2011), "Raising Potential Growth After the Crisis: A Quantitative Assessment of the Potential Gains from Various Structural Reforms in the OECD Area and Beyond", OECD Economics Department Working Papers, No. 835, OECD Publishing.

Boussard, J., F. De Castro and M. Salto (2012), "Fiscal multipliers and public debt dynamics in consolidations", European Economy, Economic Papers No 460, European Commission.

Celasun, O., X. Debrun and J. Ostry (2006), "Primary surplus behaviour and risks to fiscal sustainability in emerging market countries: a "fan-chart" approach", IMF Working Paper No. 06/67.

Corsetti, G., A. Meier, G. Müller (2012), “What Determines Government Spending Multipliers?”, IMF Working Paper No. 12/150.

Cottarelli C. and Jaramillo L. (2012), "Walking Hand in Hand: Fiscal Policy and Growth in Advanced Economies", IMF Working Paper No. 12/137.

Dias, A. and E. Lopes (2009), “A Multisectoral Model for Portugal with a Multiregional Extension”, Portuguese Department of Foresight and Planning and International Affairs, presentation for the $17^{\text {th }}$ International Input-Output Conference São Paulo, Brazil, 13-17 July.

Delong, B. and L. Summers (2012), "Fiscal policy in a depressed economy", paper presented at the Spring 2012 Brookings Panel.

Di Giovanni, J. and E. Gardner (2008), "A simple stochastic approach to debt sustainability applied to Lebanon”, IMF Working Paper No. 08/97.

ECB (2012), Monthly Bulletin, March, pp. 97-98.

European Commission (2012), "The economic adjustment programme for Portugal, Third review", Occasional Paper No. 95, April.

Girouard, N. and C. André (2005), "Measuring Cyclically adjusted Budget Balances for OECD Countries", OECD Economics Department Working Papers, No. 434, OECD Publishing.

Guichard, S., D. Haugh and D. Turner (2009), "Quantifying the Effect of Financial Conditions in the Euro Area, Japan, United Kingdom and United States”, OECD Economics Department Working Papers, No. 677, OECD Publishing. 
ECO/WKP(2012)61

IMF (2012), “Third Review Under the Extended Arrangement and Request for a Waiver of Applicability of End-March Performance Criteria", IMF Country Report, No. 12/77, International Monetary Fund.

Lenain P., R. Hagemann and D. Carey (2010), "Restoring Fiscal Sustainability in the United States", OECD Economics Department Working Papers, No. 806, OECD Publishing.

OECD (2011), Economic Outlook No. 90, OECD Publishing.

OECD (2012), Economic Outlook No. 91, OECD Publishing.

Portuguese Government (2012), Documento de Estratégia Orçamental 2012-2016. 


\section{WORKING PAPERS}

The full series of Economics Department Working Papers can be consulted at www.oecd.org/eco/workingpapers/

983. The German labour market: preparing for the future (September 2012) by Felix Hüfner and Caroline Klein

982. Climate change policies in Germany: make ambition pay (September 2012) by Caroline Klein

981. Restarting the growth engine in Finland (September 2012) by Henrik Braconier

980. Import Competition, Domestic Regulation and Firm-Level Productivity Growth in the OECD (September 2012) by Sarra Ben Yahmed and Sean Dougherty

979. Non-Parametric Stochastic Simulations to Investigate Uncertainty around the OECD Indicator Model Forecasts (August 2012) by Elena Rusticelli

978. Measuring GDP Forecast Uncertainty using Quantile Regressions (July 2012) by Thomas Laurent and Tomasz Kozluk

977. Implications of output gap uncertainty in times of crisis (July 2012) by Romain Bouis, Boris Cournède and Ane Kathrine Christensen

976. Avoiding debt traps: financial backstops and structural reforms (July 2012) by Pier Carlo Padoan, Urban Sila and Paul van den Noord

975. Sluggish productivity growth in Denmark: the usual suspects? (July 2012) by Müge Adalet McGowan and Stéphanie Jamet

974. Towards green growth in Denmark: improving energy and climate change policies (July 2012) by Stéphanie Jamet

973. An Analysis of Productivity Performance in Spain before and during the Crisis: Exploring the Role of Institutions (June 2012) Juan S. Mora-Sanguinetti and Andrés Fuentes

972. Europe's new fiscal rules (June 2012) by Sebastian Barnes, David Davidsson and Łukasz Rawdanowicz

971. Credit Crises and the Shortcomings of Traditional Policy Responses (June 2012) by William R. White

970. International Capital Mobility and Financial Fragility

Part 7. Enhancing Financial Stability: Country-specific Evidence on Financial Account and Structural Policy Positions

(June 2012) by Rudiger Ahrend and Carla Valdivia 
969. International Capital Mobility and Financial Fragility

Part 6. Are all Forms of Financial Integration Equally Risky in Times of Financial Turmoil? Asset Price Contagion during the Global Financial Crisis

(June 2012) by Rudiger Ahrend and Antoine Goujard

968. International Capital Mobility and Financial Fragility

Part 5. Do Investors Disproportionately Shed Assets of Distant Countries under Increased

Uncertainty? Evidence from the Global Financial Crisis

(June 2012) by Rudiger Ahrend and Cyrille Schwellnus

967. International Capital Mobility and Financial Fragility

Part 4. Which Structural Policies Stabilise Capital Flows when Investors Suddenly Change their

Mind? Evidence from Bilateral Bank Data

(June 2012) by Rudiger Ahrend and Cyrille Schwellnus

966. International Capital Mobility and Financial Fragility

Part 3. How do Structural Policies affect Financial Crisis Risk? Evidence from Past Crises across $O E C D$ and Emerging Economies

(June 2012) by Rudiger Ahrend and Antoine Goujard

965. Sustaining Korea's convergence to the highest-income countries

(June 2012) by Randall S. Jones and Satoshi Urasawa

964. Achieving the "low carbon, green growth" vision in Korea

(June 2012) by Randall S. Jones and Byungseo Yoo

963. Promoting social cohesion in Korea

(June 2012) by Randall S. Jones and Satoshi Urasawa

962. Housing price and investment dynamics in Finland

(May 2012) by Christophe André and Clara Garcia

961. Improving health outcomes and system in Hungary

(May 2012) by Mehmet Eris

960. Towards a more inclusive labour market in Hungary

(May 2012) by Rafał Kierzenkowski

959. Ensuring stability and efficiency of the Hungarian financial sector

(May 2012) by Olena Havrylchyk

958. Ensuring debt sustainability amid strong economic uncertainty in Hungary

(June 2012) by Pierre Beynet and Rafał Kierzenkowski

957. Improving the health-care system in Poland

(April 2012) by Hervé Boulhol, Agnieszka Sowa and Stanislawa Golinowska

956. Options for benchmarking infrastructure performance

(April 2012) by Mauro Pisu, Peter Hoeller and Isabelle Joumard. 